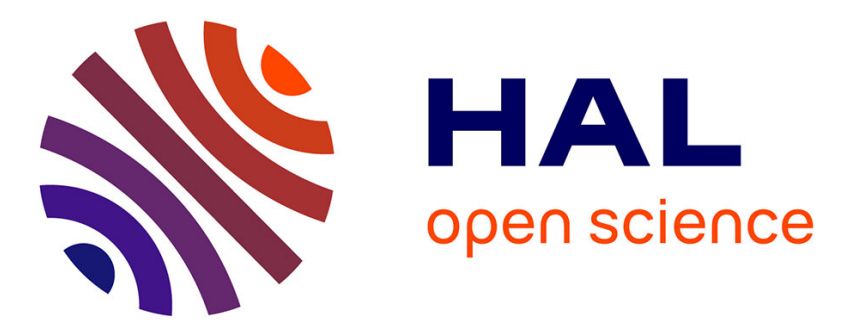

\title{
Reassessment of the involvement of Snord115 in the serotonin 2c receptor pathway in a genetically relevant mouse model
}

Jade Hebras, Virginie Marty, Jean Personnaz, Pascale Mercier, Nicolai Krogh, Henrik Nielsen, Marion Aguirrebengoa, Hervé Seitz, Jean-Phillipe Pradere, Bruno P Guiard, et al.

\section{To cite this version:}

Jade Hebras, Virginie Marty, Jean Personnaz, Pascale Mercier, Nicolai Krogh, et al.. Reassessment of the involvement of Snord115 in the serotonin 2c receptor pathway in a genetically relevant mouse model. eLife, 2020, 9, 10.7554/elife.60862 . hal-03040896

\section{HAL Id: hal-03040896 https://hal.science/hal-03040896}

Submitted on 4 Dec 2020

HAL is a multi-disciplinary open access archive for the deposit and dissemination of scientific research documents, whether they are published or not. The documents may come from teaching and research institutions in France or abroad, or from public or private research centers.
L'archive ouverte pluridisciplinaire HAL, est destinée au dépôt et à la diffusion de documents scientifiques de niveau recherche, publiés ou non, émanant des établissements d'enseignement et de recherche français ou étrangers, des laboratoires publics ou privés. 


\section{Reassessment of the involvement of Snord 115 in the serotonin $2 c$ receptor pathway in a genetically relevant mouse model}

\begin{abstract}
Jade Hebras ${ }^{1 \dagger}$, Virginie Marty ${ }^{1 \dagger}$, Jean Personnaz ${ }^{2}$, Pascale Mercier ${ }^{3}$, Nicolai Krogh ${ }^{4}$, Henrik Nielsen ${ }^{4}$, Marion Aguirrebengoa ${ }^{5}$, Hervé Seitz ${ }^{6}$, Jean-Phillipe Pradere ${ }^{2}$, Bruno P Guiard ${ }^{7}$, Jérôme Cavaille ${ }^{1 *}$
\end{abstract}

${ }^{1}$ Laboratoire de Biologie Moléculaire Eucaryote, Centre de Biologie Intégrative, Université de Toulouse, CNRS, UPS, Toulouse, France; ${ }^{2}$ Institut National de la Santé et de la Recherche Médicale (INSERM), U1048, Institut National de la Santé et de la Recherche Médicale (INSERM), France Institut des Maladies Métaboliques et Cardiovasculaires (I2MC), Université de Toulouse Université Paul Sabatier, Toulouse, France; ${ }^{3}$ Institut de Pharmacologie et de Biologie Structurale (IPBS), Centre National de la Recherche Scientifique UMR5089, Toulouse, France; ${ }^{4}$ Department of Cellular and Molecular Medicine, University of Copenhagen, Copenhagen, Denmark; ${ }^{5}$ LBCMCP, Centre de Biologie Intégrative (CBI), CNRS, Université de Toulouse, Toulouse, France; ${ }^{6} \mathrm{GGH}$ (CNRS and University of Montpellier), Montpellier, France; ${ }^{7}$ Centre de Recherches sur la Cognition Animale (CRCA), Centre de Biologie Intégrative (CBI), Centre National de la Recherche Scientifique, Université de Toulouse, Toulouse, France

Abstract SNORD115 has been proposed to promote the activity of serotonin (HTR2C) receptor via its ability to base pair with its pre-mRNA and regulate alternative RNA splicing and/or A-to-I RNA editing. Because SNORD115 genes are deleted in most patients with the Prader-Willi syndrome (PWS), diminished HTR2C receptor activity could contribute to the impaired emotional response and/or compulsive overeating characteristic of this disease. In order to test this appealing but never demonstrated hypothesis in vivo, we created a CRISPR/Cas9-mediated Snord115 knockout mouse. Surprisingly, we uncovered only modest region-specific alterations in Htr2c RNA editing profiles, while $\mathrm{Htr} 2 \mathrm{c}$ alternative RNA splicing was unchanged. These subtle changes, whose functional relevance remains uncertain, were not accompanied by any discernible defects in anxiodepressive-like phenotypes. Energy balance and eating behavior were also normal, even after exposure to high-fat diet. Our study raises questions concerning the physiological role of SNORD115, notably its involvement in behavioural disturbance associated with PWS.

\section{Introduction}

Box C/D small nucleolar RNAs (SNORDs) represent a well-defined family of small non-coding RNAs that exert their regulatory functions via antisense-based mechanisms. Indeed, the vast majority forms base-pairing interactions with ribosomal RNA (rRNA) precursor, spliceosomal U6 snRNA or tRNA and, in doing so, they guide sequence-specific ribose methylations (Cavaillé et al., 1996; Ganot et al., 1999; Kiss-László et al., 1996; Vitali and Kiss, 2019) or, in rare cases, base acetylation (Sharma et al., 2017). By acting as RNA folding chaperones, a few are specialized to facilitate 
the production of mature 18S, 28S, and 5.8S rRNA (Watkins and Bohnsack, 2012). Finally, nucleoli also contain orphan SNORDs lacking conserved antisense elements against canonical RNA targets, thus raising the possibility that some may interact with uncharacterized targets, possibly including mRNAs (Bratkovič et al., 2020).

Intriguingly, many orphan SNORDs are generated from two large, imprinted chromosomal domains at human 15q11q13 and 14q32 (Cavaillé, 2017; Marty and Cavaillé, 2019). The imprinted human 15q11q13 region - also known as the Prader-Willi Syndrome (PWS)/Angelman Syndrome (AS) locus or SNURF-SNRPN domain - contains several paternally expressed, protein coding genes as well as numerous paternally expressed, neuronal-specific SNORD genes organized as two main repetitive DNA arrays: the SNORD116 and SNORD115 clusters composed of 29 and 47 related gene copies, respectively (Cavaillé et alo, 2000). The lack of expression of one (or several) paternally expressed gene(s) on $15 q 11 q 13$ is genetically linked to Prader Willi Syndrome (Buiting, 2010; Cassidy et al., 2012). This rare human genetic disorder is characterized by poor feeding and muscular hypotonia in the perinatal period while, in the childhood and adulthood, individuals with PWS manifest an obsession with food and eating that, if not controlled, leads to life-threatening obesity. Other symptoms include decreased energy expenditure, growth delay, abnormalities in hormonal profiles, hypogonadism, dysfunction of the hypothalamus-pituitary axis, respiratory problems, high pain threshold, sleep disturbance, learning disabilities as well as diverse psychopathological issues notably in terms of obsessive-compulsive behavior and anxio-depressive traits (Butler et al., 2019; Cassidy et al., 2012; Muscogiuri et al., 2019; Thuilleaux et al., 2018).

Although the genotype-phenotype relationship in PWS is complex and not entirely understood, deficiencies in SNORDs have recently emerged as one of the key determinants for the disease. This is evidenced by rare PWS individuals bearing $~ 71-200 \mathrm{~kb}$-long paternally inherited deletions overlapping the SNORD gene array, particularly SNORD116 genes (Bieth et al., 2015; de Smith et al., 2009; Duker et al., 2010; Fontana et al., 2017; Sahoo et al., 2008; Tan et al., 2020). Remarkably, Snord116-deficient mice are growth-retarded and show increased food intake, two abnormalities reminiscent of PWS phenotype (Ding et al., 2008; Skryabin et al., 2007). The relevance of increased food intake with respect to the lower body weight of Snord116 mutants was, however, recently questioned (Polex-Wolf et al., 2018). Importantly, loss of Snord116 is not accompanied by any signs of obesity and, paradoxically, Snord116-deficient mice appear even protected from high fat-diet induced obesity (Ding et al., 2008; Qi et al., 2016). Thus, Snord116-KO mice, like all other PWS mouse models, do not fully recapitulate the entire set of PWS phenotypes (Bervini and Herzog, 2013).

The SNORD115 gene locus has attracted particular attention due to its predicted involvement in promoting the synthesis of serotonin HTR2C receptor with optimal signaling properties (Cavaillé, 2017; Cavaillé et al., 2000; Stamm et alı, 2017), very likely by fine-tuning alternative RNA splicing and/or adenosine (A)-to-inosine (I) RNA editing of HTR2C pre-mRNA (Kishore and Stamm, 2006; Vitali et al., 2005). Indeed, a growing body of observations supports a functional link between SNORD115, HTR2C, and PWS. First, adult mice bearing a constitutive inactivation of the Htr2c gene are hyperphagic and overweight (Nonogaki et alı, 1998; Tecott et al., 1995). Second, increased food intake and growth retardation were reported in knock-in mice that only produce the fully edited (VGV), less active HTR2C isoform (Kawahara et al., 2008; Morabito et al., 2010a). Third, induced changes in Htr2c alternative splicing patterns mediated by antisense oligonucleotides alter food intake in mice (Zhang et al., 2016). Fourth, defects in HTR2C pathways, including altered RNA editing, are involved in the pathophysiology of psychiatric disorders, particularly anxiety, depression, obsessive-compulsive behaviors, and schizophrenia (Chagraoui et al., 2016). Fifth, and perhaps even more tellingly, defects in Htr2c-related behaviors were described in the PWS-IC mouse model in which all paternally inherited alleles in the cluster are silenced (Davies et al., 2019; Doe et al., 2009; Garfield et al., 2016). Altogether, defective post-transcriptional processing of HTR2C pre-mRNA - and thus impaired HTR2C pathway - has been surmised to account for overeating and anxio-depressive phenotypes frequently encountered in PWS patients (Cavaillé, 2017; Stamm et al., 2017), although the loss of SNORD115 is unlikely to be sufficient to elicit PWS (Bürger et al., 2002; Runte et al., 2005). This model was first proposed 20 years ago, and it constitutes certainly the most convincing example advocating for an involvement of SNORD in modifying a protein-coding transcript (Cavaillé et al., 2000). Yet, direct proofs supporting this appealing SNORD115/HTR2C axis are still lacking at the organism level (Cavaillé, 2017). As a corollary, 
whether lack of SNORD115 per se is sufficient to trigger altered HTR2C-signaling pathways and, in doing so, leads to behavioral abnormalities remains to be formally demonstrated. Hence, probing the mode of action of SNORD115 in vivo is not only a prerequisite to further our understanding of the pathophysiology of PWS but it is also of immediate interest to uncover novel SNORD-mediated functions in the brain.

Here, we generated a CRISPR-Cas9-mediated specific Snord115 gene knockout (KO) mouse model to better understand the functional relevance of Snord115 in influencing Htr2c pre-mRNA processing and HTR2C-related behaviors (e.g. eating and emotional response). We unexpectedly showed that constitutive deletion of the entire Snord115 gene array does not greatly alter the posttranscriptional regulation of Htr2c pre-mRNA, nor does it affect emotionality, homeostatic feeding or energy balance, either on normal chow or high-fat diets. In contrast to common belief, we thus conclude that a constitutive loss of Snord115 has a relatively modest impact on two well-known HTR2C-mediated physiological processes.

\section{Results}

\section{CRISPR-Cas9-mediated disruption of the Snord115 gene array}

Snord115 is processed from repeated, regularly spaced introns of a poorly characterized noncoding RNA host-gene transcript (Figure 1A). Snord115 sequences are the only conserved DNA segments in placental mammals, strongly arguing that this atypical transcription unit encodes functional small RNA species under selective pressure (Cavaillé et al., 2000). In order to probe the physiological relevance of Snord115 in vivo, we engineered a KO mouse model carrying a targeted, constitutive CRISPR/Cas9-mediated deletion removing the entire Snord115 gene array (Figure 1A-B). Because Snord115 genes are only expressed from the paternal allele, $\sim 50 \%$ of Snord115-deficient mice are expected to be obtained in the progeny after crossing wild-type females with heterozygous males. Indeed, the Snord115 gene array is no longer expressed upon a paternally inherited deletion while, as expected, its expression remains unaffected upon maternal transmission of the deletion (Figure 1C). Moreover, we were also unable to detect Snord115 expression by RT-qPCR in several manually-dissected brain structures from adult mice bearing a paternally-inherited deletion (Figure 1D). Importantly, the removal of Snord115 genes does not significantly alter the expression of the neighboring imprinted genes (Figure 1E), including that of the anti-Ube3a transcript thought to silence the paternal Ube3a allele in cis (Figure 1F). Altogether, these important controls render unlikely the possibility that we removed critical regulatory regions controlling imprinted expression over the domain. Finally, in order to limit confounding effects due to genetic heterogeneity and/or undesired CRISPR-Cas9-mediated cleavages, if any, we also backcrossed to C57BL/6J background for at least eight generations before proceeding to phenotypic exploration. The term Snord115-deficient or Snord115-KO mice will thus be used to refer to heterozygous mice with a paternally inherited deletion. Snord115-deficient mice are seemingly normal and progeny was obtained at expected Mendelian and sex ratios, leaving unlikely any developmental defect and/or perinatal lethality.

\section{The repertoire of 2'-O-methylations of ribosomal RNAs remains unchanged in the adult brain of Snord115-deficient mice}

Snord115 is a massively-expressed, neuronal-specific SNORD that stably associates with the 2'-Omethyltransferase Fibrillarin in vivo and accumulates in the nucleolus (Bortolin-Cavaillé and Cavaillé, 2012; Cavaillé et al., 2000). Yet, it lacks an antisense element that can guide Fibrillarin to rRNA targets, arguing against a direct role in specifying neuronal-specific rRNA 2'-O-methylation(s). In agreement with this assumption, our recent study failed to identify any brain-specific methylation rRNA sites (Hebras et al., 2020). We nevertheless hypothesized that high Snord115 levels in neurons may impact on rRNA methylation profiles, possibly by modulating the availability of other SNORD-associated binding proteins. To address this, RiboMeth-seq was applied to adult whole brains from WT and Snord115-deficient mice. As reported in Figure 1G, the overall rRNA methylation patterns were comparable between WT and Snord115-KO brain, with only slight changes in methylation levels at a few rRNA sites: SSU-A576, LSU-C1868, and 5.8S-U14. Since methylation levels at these three positions were unaffected in the developing (E16.5) brain of another mouse model where Snord115 and 
A

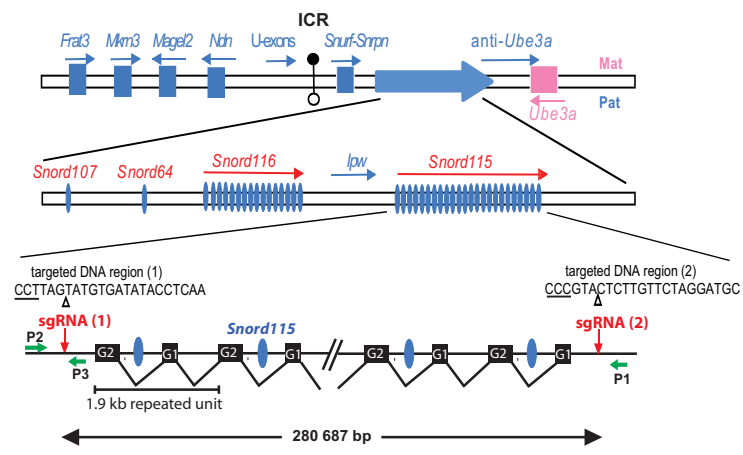

Expected : ccCACATAATAACCTTAGCTCTTGTTCTAGGATGCTATG Observed: CCCACATAATAACCTT - - -..--GTTCTAGGATGCTATG

D

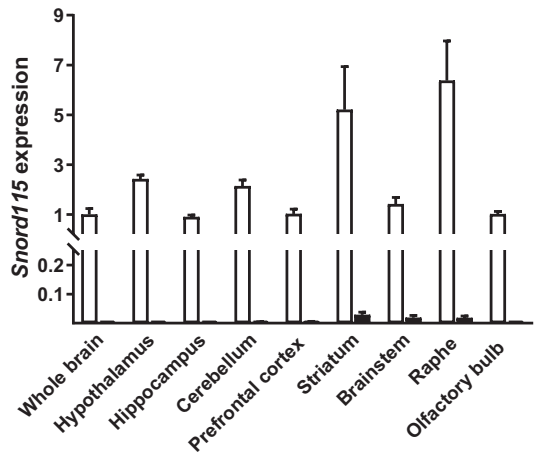

B

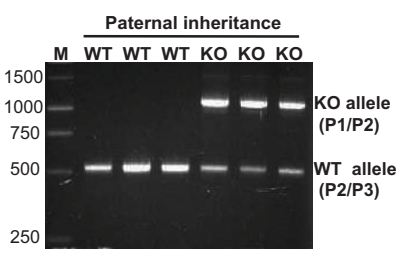

C

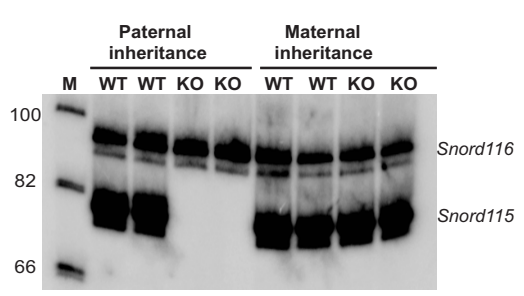

E

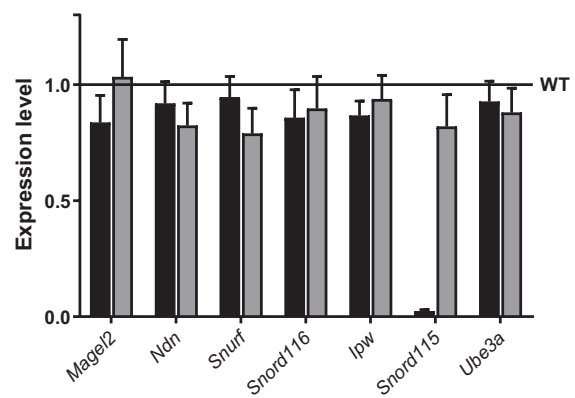

$\mathbf{F}$

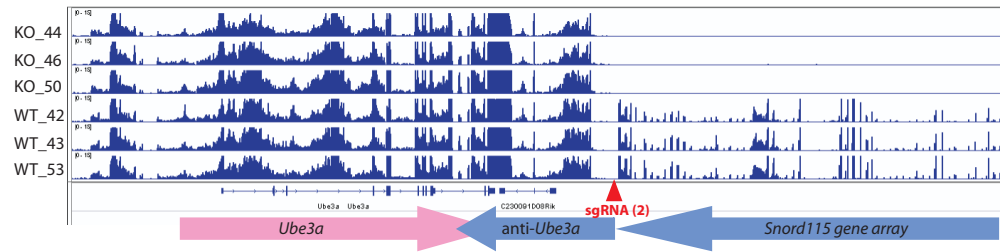

G

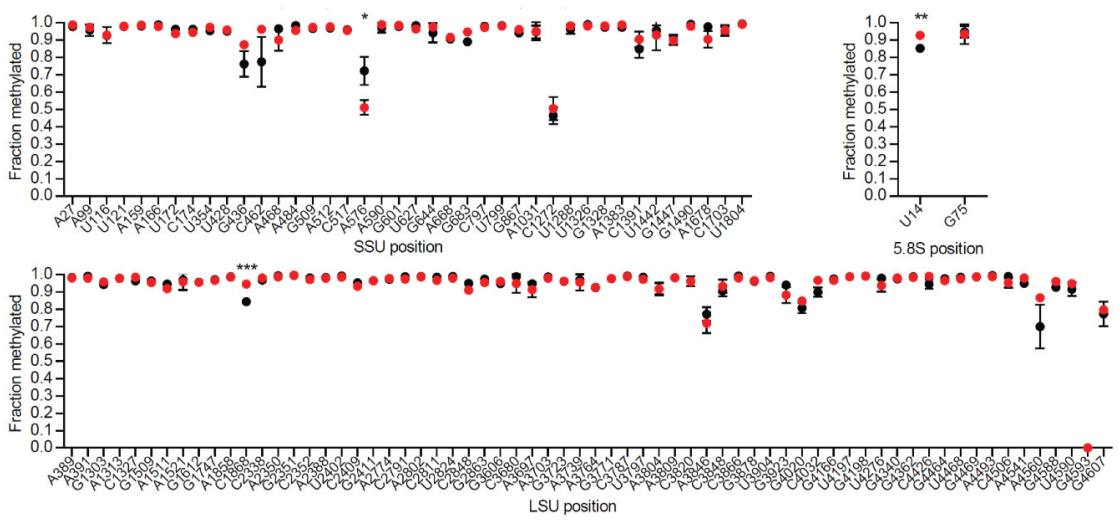

Figure 1. Targeted deletion of the paternally expressed Snord115 genes. (A) Schematic representation of the imprinted Snurf-Snrpn region on mouse chromosome 7 c, also commonly known as the imprinted PWS region at human 15q11q13. Paternally expressed and maternally expressed proteincoding genes are symbolized by blue and pink rectangles, respectively. The paternally expressed SNORD gene array composed of Snord107, Snord64 and the tandemly repeated Snord116 and Snord115 gene families is depicted by a large, horizontal blue arrow while poorly defined noncoding Figure 1 continued on next page 
Figure 1 continued

transcript (U-exons, anti-Ube3A and Ipw) are denoted with thin arrows. SNORD gene copies are denoted as vertical blue ovals. The Imprinting Centre Region (ICR) that controls imprinted expression over the domain is represented by filled and open lollipops (methylated and un-methylated alleles, respectively). Each Snord115 gene copy is intron-encoded within a $\sim 1.9 \mathrm{~kb}$ tandemly- repeated unit spreading over a $\sim 280 \mathrm{~kb}-$ long noncoding DNA region. The two targeted DNA sequences by sgRNA(1) and sgRNA(2), as well as the theoretical and observed editing events at the deletion junction, are shown. The PAM sequence is underlined and the position of the predicted cleavage sites are indicated (positions 17 and 18 of the sgRNA). The genomic coordinates of the expected deletion is mm10 chr7:59,340,581-59,621,267. Green arrows represent the relative positions of P1, P2, and P3 primers used for PCR genotyping. Scale is not respected. (B) PCR genotyping of WT and mutant mice carrying a paternally-inherited deletion using a mixture of P1, P2, and P3 primers. (C) Expression of Snord115 and Snord116 was assayed (northern blot) in whole brains from heterozygous mice having a paternally- or maternally-transmitted deletion and WT littermates ( $n=2$ individuals per genotype). (D) Black and white bars represent Snord115 expression (RT-qPCR relative to Gapdh) in several brain areas dissected from mice bearing a paternally inherited deletion and WT littermates, respectively ( $n=8-12$ per genotype). (E) Black and gray bars represent expression levels (RT-qPCR relative to Gapdh) of flanking imprinted genes in the whole brain of mice bearing a paternally and maternally inherited deletion, respectively ( $n=4-6$ per genotype). Expression levels of WT were arbitrarily set to 1. (F) IGV screenshot showing that a targeted deletion of Snord115 gene array does not perturb the expression at the Ube3A/anti-Ube3A gene locus (mRNA-seq datasets generated from hypothalamus; supplementary file 3). (G) Methylation levels (RiboMeth-seq) at 2'-O-methylated rRNA sites in WT (black circles) and Snord115-deficient (red circles) adult brain ( $\mathrm{n}=3$ per genotype). Nucleotide numbering is according to human rRNA (Krogh et al., 2016). Asterisks indicate statistical significance levels.

The online version of this article includes the following figure supplement(s) for figure 1:

Figure supplement 1. Loss of Snord116 and Snord115 does not impact on rRNA methylation profiles in the adult brain.

Snord116 genes are simultaneously deleted (Figure 1-figure supplement 1 and supplementary file 1), we thus conclude that neither Snord115, nor Snord116 play a prominent role in ribose methylation of rRNAs.

\section{Snord115 does not influence alternative RNA splicing of Htr2c pre- mRNA}

The Htr2c pre-mRNA is alternatively spliced through the use of two $5^{\prime}$ donor splice sites (5'-SS) (Figure 2A). The regular 5'-SS generates RNA2 encoding the full-length receptor while a cryptic 5'SS yields an alternatively spliced transcript (RNA1) that generates a truncated, presumably non-functional receptor. The binding of Snord115 nearby the cryptic 5'-SS was proposed to favor the production of RNA2 (Cavaillé et al., 2000; Doe et al., 2009; Garfield et al., 2016; Kishore and Stamm, 2006). According to this model, the RNA2-to-RNA1 ratio should decrease in the absence of Snord115. As shown in Figure 2B, the steady state levels of Htr2c mRNAs, as assayed by a couple of primers matching the $5^{\prime}$-UTR, were globally unchanged in whole brain as well as in eight manually-dissected brain regions of adult Snord115-deficient mice. Only striatum showed a significant increase in Htr2c mRNA abundance, as compared to WT. We then tested the lack of Snord115 on alternative splicing of $\mathrm{Htr} 2 \mathrm{c}$ pre-mRNA by measuring the RNA2-to-RNA1 ratio by RT-qPCR. Again, lack of Snord115 did not cause any obvious changes in the profiles of alternative splicing, including in spinal cord (Figure 2C -left). Adult hypothalamus even displayed a slight increase in the RNA2-toRNA1 ratio. This effect was, however, not seen in another independent cohort (not shown). As controls, and in agreement with previous findings (Canton et al., 1996), choroid plexus showed highest RNA1 level as compared to hypothalamus (Figure 2C -right), thus indicating that our RT-qPCR procedure is capable of detecting changes in the RNA2-to-RNA1 ratio. Finally, we demonstrated unaltered alternative splicing of hypothalamic Htr2c pre-mRNAs by RT-PCR analysis with a pair of primers that simultaneously detected RNA2 and RNA1 (Figure 2D). Thus, our findings do not support a central role of Snord115 in modulating alternative splicing of Htr2c pre-mRNA in vivo.

\section{The lack of Snord115 has a weak impact on RNA editing of Htr2c pre- mRNA}

Through the action of ADAR2 and ADAR1, Htr2c pre-mRNA undergoes site-specific A-to-I RNA editing at five adenosines clustered in exon V: the A-, B-, C-, D-, and E- sites (Figure 3A -top; Burns et al., 1997). Strikingly, Snord115 is predicted to target the C-site for 2'-O-methylation (Figure 2A; Cavaillé et al., 2000). Inosines are interpreted as guanosines during translation and, accordingly, these nucleotide changes result in alteration of three amino acids positioned within the second intracellular loop of the receptor. The protein recoding events lead to the production of 24 


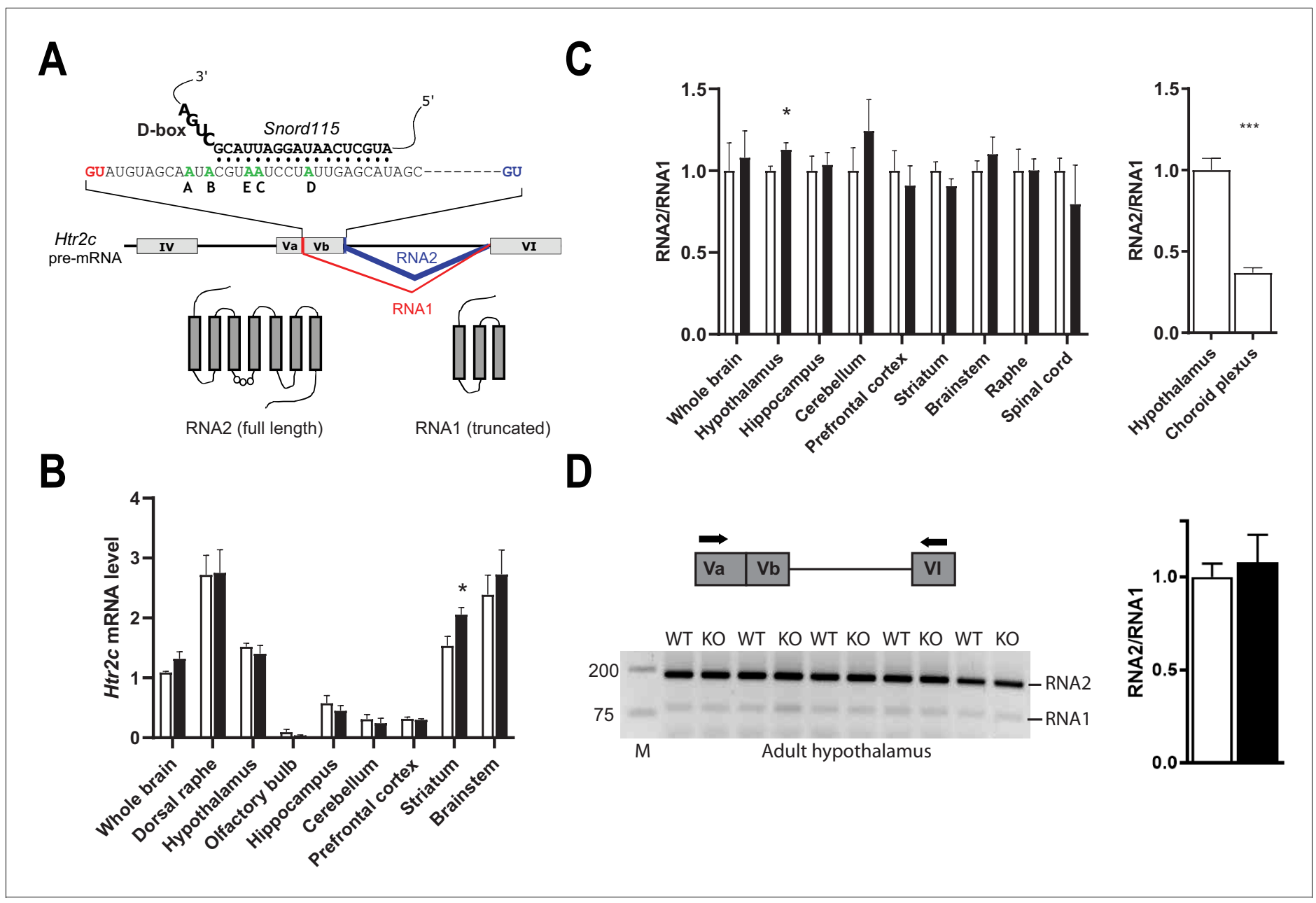

Figure 2. Alternative RNA splicing of Htr2c pre-mRNA remains unaffected in Snord115-deficient brains. (A) Through the use of regular (blue) and alternative (red) 5' splice sites, RNA splicing of Htr2c pre-mRNA generates RNA2 and RNA1 transcripts that encode full length and truncated HTR2C receptor, respectively. Htr2c pre-mRNA undergoes A-to-I RNA editing at five adenosines (green), denoted as the A, B, C, D, and E editing sites. Snord115 has the potential to target the C-site for 2'-O-methylation, that is the position paired to the fifth nucleotide upstream of the D-box (CUGA). (B) Black and white bars represent Htr2c mRNA expression levels (RT-qPCR relative to Gapdh) in whole brain and manually dissected brain regions of Snord115-deficient mice and WT littermates, respectively ( $n=5-8$ per genotype). (C) Left: Black and white bars show the RNA2-to-RNA1 ratio (RTQPCR) in whole brain and manually dissected brain regions of adult Snord115-deficient mice and WT littermates, respectively ( $n=6$ per genotype). RNA2-to-RNA1 ratios in WT were set to 1. Right: Histograms show the RNA2-to-RNA1 ratio (RT-qPCR) in hypothalamus and choroid plexus of adult WT mice, respectively ( $n=5-6$ per tissue). The RNA2-to-RNA1 ratio in hypothalamus was set to 1 (D) Left: Ethidium bromide staining of RT-PCR products obtained in hypothalamus of Snord115-deficient and WT littermates using a pair of primers (horizontal black arrows) that simultaneously detect RNA2 and RNA1, as illustrated above the gel. M, Marker (bp). Right: intensity of PCR signals was quantified and RNA2-to-RNA1 in WT was set to 1.

different HTR2C receptors translated from 32 distinct mRNAs. Remarkably, RNA editing influences HTR2C response with increased RNA editing correlating with diminished G-protein coupling efficacy and reduced constitutive activity. Of note, editing at the $\mathrm{C}$ - and E-sites plays a pivotal role in modulating the HTR2C signaling pathway (Berg et alı, 2001; Burns et alı, 1997; Fitzgerald et alo, 1999; Niswender et al., 1999; Wang et alo, 2000). Given that introducing a 2'-O-methylation at an editing site specifically decreases ADAR-mediated deamination in vitro (Yi-Brunozzi et alo, 1999), we logically anticipated that editing at the target $\mathrm{C}$-site should increase in Snord115-deficient mice as previously proposed based on artificial, non-neuronal cell systems (Vitali et alo, 2005). To address this, we quantified A-to-I RNA editing in whole brain and spinal cord as well as in eight manually dissected brain regions using deep sequencing of cDNA of spliced Htr2c mRNA followed by scoring A-to-G mismatches between RNA-seq reads and genomic sequence (Figure 3A -lower 
A
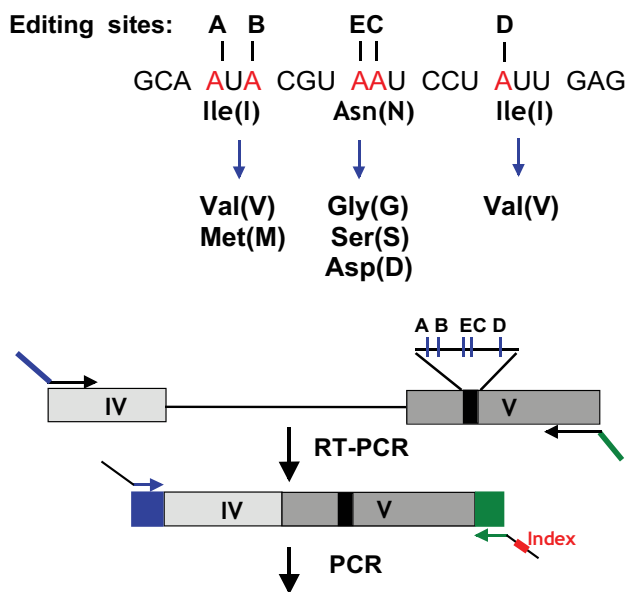

Illumina deep sequencing ( 1 million reads/genotype)

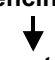

Search for A-to-G mismatches (genomic vs RNA-seq reads)

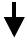

Analyses of Htr2c RNA editing in brain regions
B
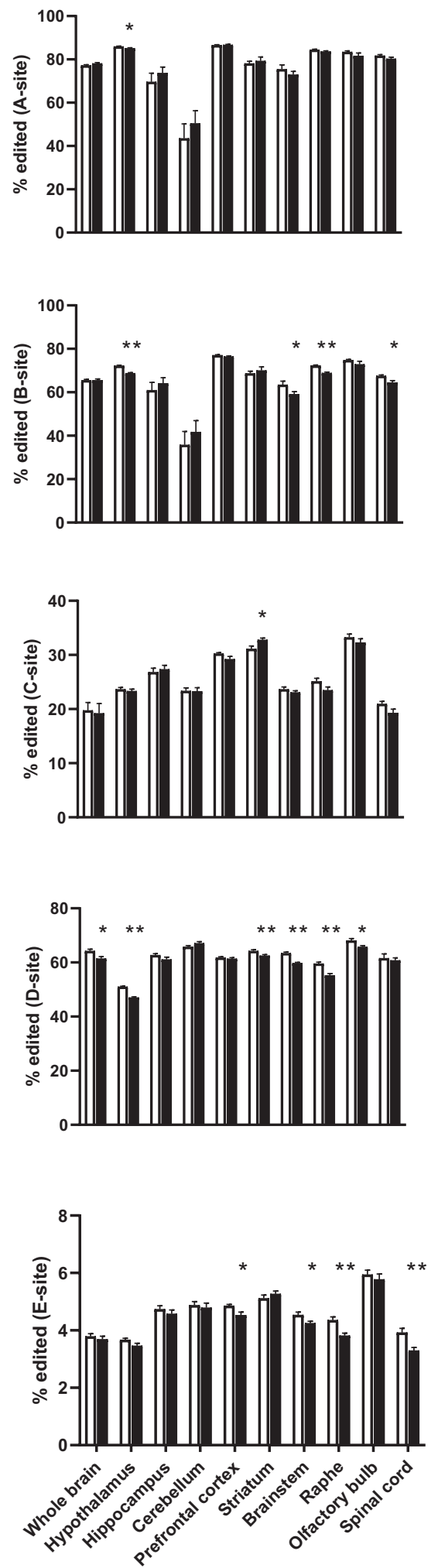

Figure 3. Loss of Snord115 has a mild influence on Htr2c RNA editing profiles. (A) Upper part: sequence-specific A-to-I RNA editing alters the genetic information embedded in exon $\mathrm{V}$ of Htr2c mRNA. Lower part: High-throughput sequencing method to measure RNA editing of Htr2c mRNA. (B) Percentage of RNA editing at each individual site in whole brain, spinal cord as well as in eight manually dissected brain regions of Snord115-deficient (black bars) mice and WT littermates (white bars; $n=9-12$ per genotype). (C) The table lists significant changes ( $p<0.05)$ in the proportion of Htr2c Figure 3 continued on next page 
Figure 3 continued

isoforms in Snord115-deficient brain regions as indicated by the KO-to-WT ratio. The relative abundance of differentially expressed Htr2c isoforms, as measured in WT, is also indicated (\%).

The online version of this article includes the following figure supplement(s) for figure 3 :

Figure supplement 1. Loss of Snord115 and/or Snord116 has a mild impact on Htr2c RNA editing during development or after chronic mCPP treatment.

part). This high-throughput sequencing method allows reliable analyses of RNA editing (Morabito et al., 2010b). Indeed, given the high sequencing coverage $(\sim 1$ million reads per genotype) and the substantial number of mice analyzed ( $n=8-12$ per genotype), there was little intermouse variability, with highly similar editing patterns to those previously published: the $A, B$, and $D$ sites being more edited compared to $C$ and $E$ sites (Abbas et al., 2010; Morabito et al., 2010b). Our analyses showed that editing frequencies at each of the five individual sites remained globally unaltered in Snord115-KO mice. Nevertheless, we identified a few alterations at a magnitude ranging from 1 to 4\%, particularly in the hypothalamus, brainstem, and raphe (Figure 3B). Regarding the relative proportions of Htr2c isoforms (Figure $3 \mathrm{C}$ ), we observed altered expression for 44 isoforms, with most of them (28 out of 44) corresponding to lowly expressed Htr2c transcripts accounting for less than $5 \%$ of the total. These changes could not have been anticipated in a straightforward manner based on the most parsimonious interpretation stating that Snord115 targets the C-site for 2'-Omethylation (Cavaillé et al., 2000; Vitali et al., 2005). Because Htr2c RNA editing increases over time, from embryogenesis to adulthood (Wahlstedt et alo, 2009), we reasoned that lack of Snord115 could be more detrimental during dynamic changes in RNA editing. We thus quantified editing at E16.5 of development in whole brain as well as in hypothalamus, cortex, and hippocampus. As expected, adult tissues displayed an overall increase in editing as compared to their E16.5 counterparts. However, the comparison of Snord115-deficient samples with WT did not reveal any significant differences in editing levels at any of the five sites, except for slight increase at the B-site and a very few changes in mRNA isoforms for prefrontal cortex (Figure 3-figure supplement 1). Finally, Htr2c RNA editing profiles also remained largely unaltered in hypothalamus of adult mice chronically treated with the preferential HTR2C agonist meta-chlorophenylpiperazine (mCPP), or even in P1 or adult hypothalamus of mice simultaneously deleted for Snord115 and Snord116 genes (Figure 3-figure supplement 1). Altogether, our high-throughput sequencing strategy found little support for a pronounced effect of Snord115 on the regulation of Htr2c RNA editing in vivo and the functional relevance, if any, of the observed small magnitude changes remain uncertain.

\section{Snord115-deficient mice display normal emotional responses and sociability}

We then sought to determine whether deleting the brain-specific Snord115 genes is associated with behavioral and/or metabolic abnormalities. Because altered HTR2C signaling, including abnormal RNA editing, is linked to anxiety disorders and depressive states (Chagraoui et al., 2016; Heisler et al., 2007; Mombereau et al., 2010; Spoida et al., 2014), we first subjected a cohort of 8-12 week-old Snord115-deficient and WT mice to the open field (OF) test. This classical behavioral test simultaneously measures novelty-induced exploration and certain components of anxiety. As judged by the distance travelled (Figure 4A -left), the exploratory drive and locomotion were not altered in Snord115 mutant mice. Anxiety levels of Snord115-KO mice were also in the normal range, as evidenced by the number of entries (not shown) and time spent (Figure 4A -right) in the central zone of the OF considered as anxiogenic for rodents. The normal status of anxiety was further confirmed through the elevated plus maze (EPM) test, a cross-shaped platform that consists of two open and two closed arms elevated from the floor. Here, anxiety-like behavior is reflected by avoidance of the two open (anxiogenic) arms. Again, the frequencies of entry (not shown) and time spent (Figure 4B) in the open arms of Snord115-deficient mice were found indistinguishable from that of their WT littermates.

To evaluate other forms of emotional response, the novelty-suppressed feeding (NSF) test was used. In this test, overnight food-deprived mice are exposed to a novel, illuminated environment in which a pellet of food is presented in the center. Under these conditions, any delay in food 


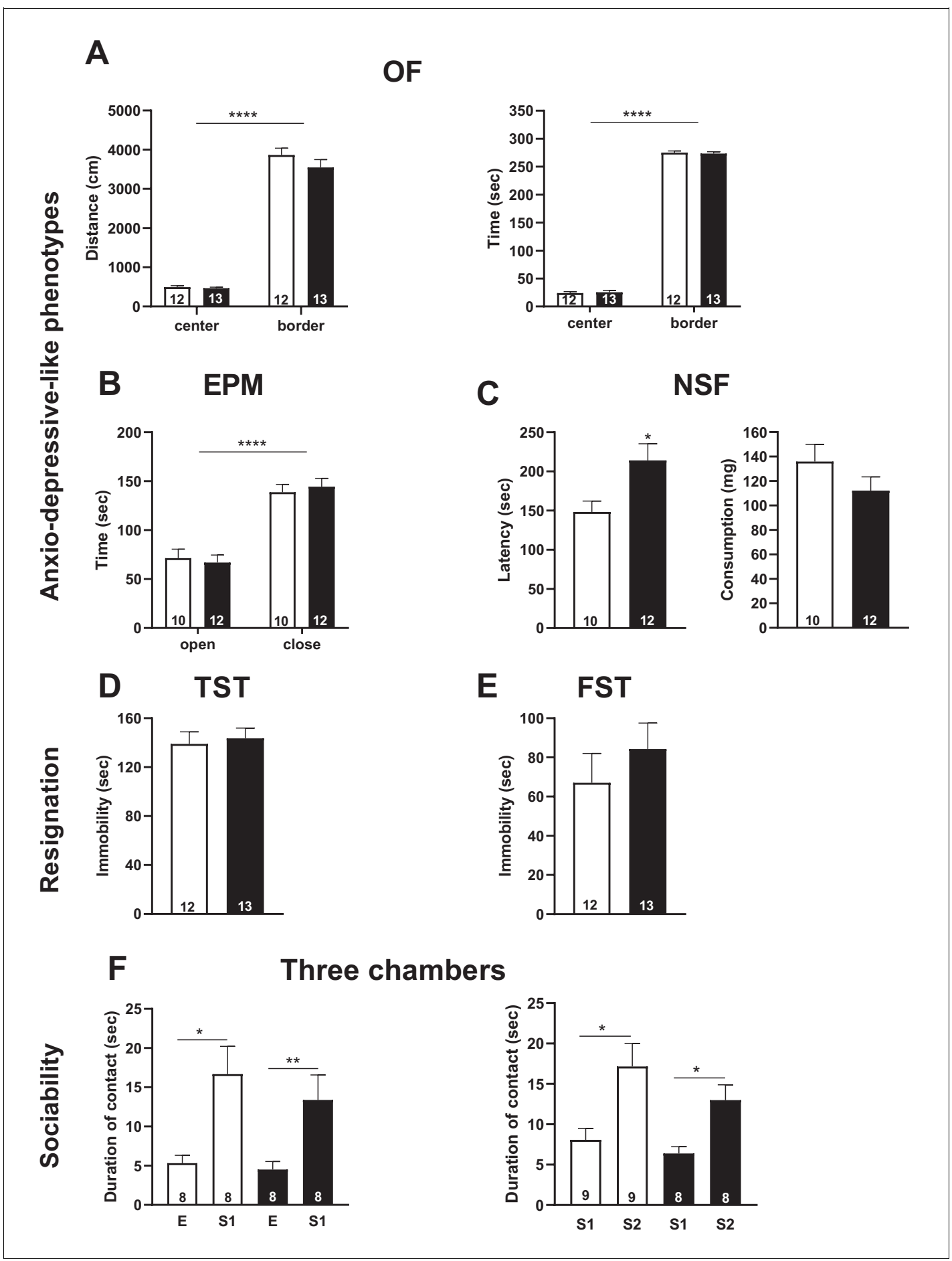

Figure 4. Snord115-deficient mice do not display abnormal anxio-depressive-like phenotypes and show normal response to sociability stimuli. Cohorts of adult Snord115-deficient males (black bars) and their WT littermates (white bars) were subjected to Open field (A), Elevated plus maze (B), Novelty supressed feeding (C), Tail suspension (D), Forced swimming (E) and Three chambers (F) tests. The number of individuals analyzed are indicated within histograms. Note that due to tracking issues, one WT individual was omitted from analysis (4F-left-panel). None of these analyses showed a significant effect of genotype (ANOVA p-values $>0.05$ for genotype in each panel). 
consumption is interpreted as mixed anxio-depressive-like behaviors. Interestingly, Snord115-KO mice showed an increase in the latency to feed compared to WT (Figure $4 C$-left). These results cannot be attributable to change in hunger since food consumption in the home cage $5 \mathrm{~min}$ after the test showed no differences between both groups (Figure 4C -right). This prompted us to employ two additional tests - the tail suspension (TST) and forced swim (FST) tests - that also interrogate a core symptom of depression such as resignation. In TST, mice are suspended by their tails with impossibility to hold onto nearby surfaces while in FST they are placed in an inescapable tank filled with water. In both paradigms, the escape behavior is monitored with immobility time used as a read-out of despair-like phenotype. As shown in Figure 4D and $E$, the duration of immobility of Snord115-deficient mice were similar to that of WT. Collectively, even though altered behavior was apparent in NSF, we nevertheless consider that Snord115-deficient mice are able to mount a normal emotional response when exposed to various acute stressors.

Mice expressing the fully edited (VGV), less active HTR2C receptor display elevated levels of social interaction including increased aggressive behaviors (Martin et al., 2013). We then investigated the sociability of Snord115-deficient mice through the three-chamber test. During the habituation session for which there is no additional mouse in the cages, WT and mutant mice contacted equally the two empty (E) compartments, thus excluding any bias for one of the two compartments (not shown). The day after, a non-familiar mouse (S1) was introduced in one of the two compartments and time spent interacting with S1 over E1 was used as an index of sociability. As shown in Figure 4F -left, both WT and Snord115-deficient mice spent more time in contacting S1 with no difference between the two genotypes. Of note, we did not detect any apparent signs of aggression. Finally, we also tested the preference for social novelty by introducing another stranger (S2) mouse. Again, we did not find any differences between WT and KO mice with, as expected, both genotypes interacting more with the novel intruder (S2) than the familiar one (S1) (Figure 4F -right). Taken together, these observations showed that social preference and recognition are unchanged in Snord115-KO mice.

\section{Snord115-deficient mice show normal spontaneous food intake and energy balance on chow diet}

Snord115 is expressed in most, if not all, pro-opiomelanocortin (Pomc) neurons in the arcuate nucleus (ARC) of the hypothalamus (supplementary file 2). The activation of HTR2C in ARC Pomc neurons, but also in nucleus of the solitary tract, promotes satiety and it also regulates body weight, energy balance, and glucose homeostasis (Berglund et al., 2013; D'Agostino et al., 2018; Heisler et al., 2002; Xu et al., 2010; Xu et al., 2008; Zhou et al., 2007). We then examined feeding behaviors and energy balance. We found that body weights (Figure 5A) and body composition (Figure 5B) of 8-week-old adult Snord115-KO mice were in the normal range as compared to WT littermates. Moreover, blood glucose levels were also unaffected and, after a bolus administration of glucose, WT and Snord115-deficient mice displayed the same ability to regulate a glucose load (Figure 5C). Food intake of Snord115-KO mice was then automatically quantified over a $24 \mathrm{hr}$ period using the TSE Phenomaster system. Both daily and nightly food intake (Figure 5D), as well as physical activity (Figure 5E), remain unaffected in mutant mice while, as expected, increased food consumption and elevated locomotion during the dark phases. Finally, indirect calorimetry did not detect any defect in energy expenditure (Figure 5F) or respiratory exchange ratio (RER; Figure 5G), either during daylight or at night. Thus, feeding behavior and energy metabolism are unlikely to be disrupted by loss of Snord115.

\section{Snord115-deficient mice display normal response to starvation}

The normal daily food intake of Snord115-deficient mice when nutrients are constantly available does not rule out potential deficiencies upon food deprivation. We then assessed response of Snord115-KO mice after $18 \mathrm{hr}$ (overnight) fasting. This was first done by measuring the steady-state levels of three ARC mRNAs encoding appetite-associated neuropeptides whose expression is affected by fasting (Baldini and Phelan, 2019; Henry et al., 2015). Figure 5H shows that our starvation procedure led, as expected, to an increase in the hypothalamic expression of the orexigenic Npy and Agrp peptide encoding mRNAs in WT mice while expression of the anorexigenic Pomc peptide encoding mRNA exhibited a tendency to decrease. Remarkably, the three above-mentioned 


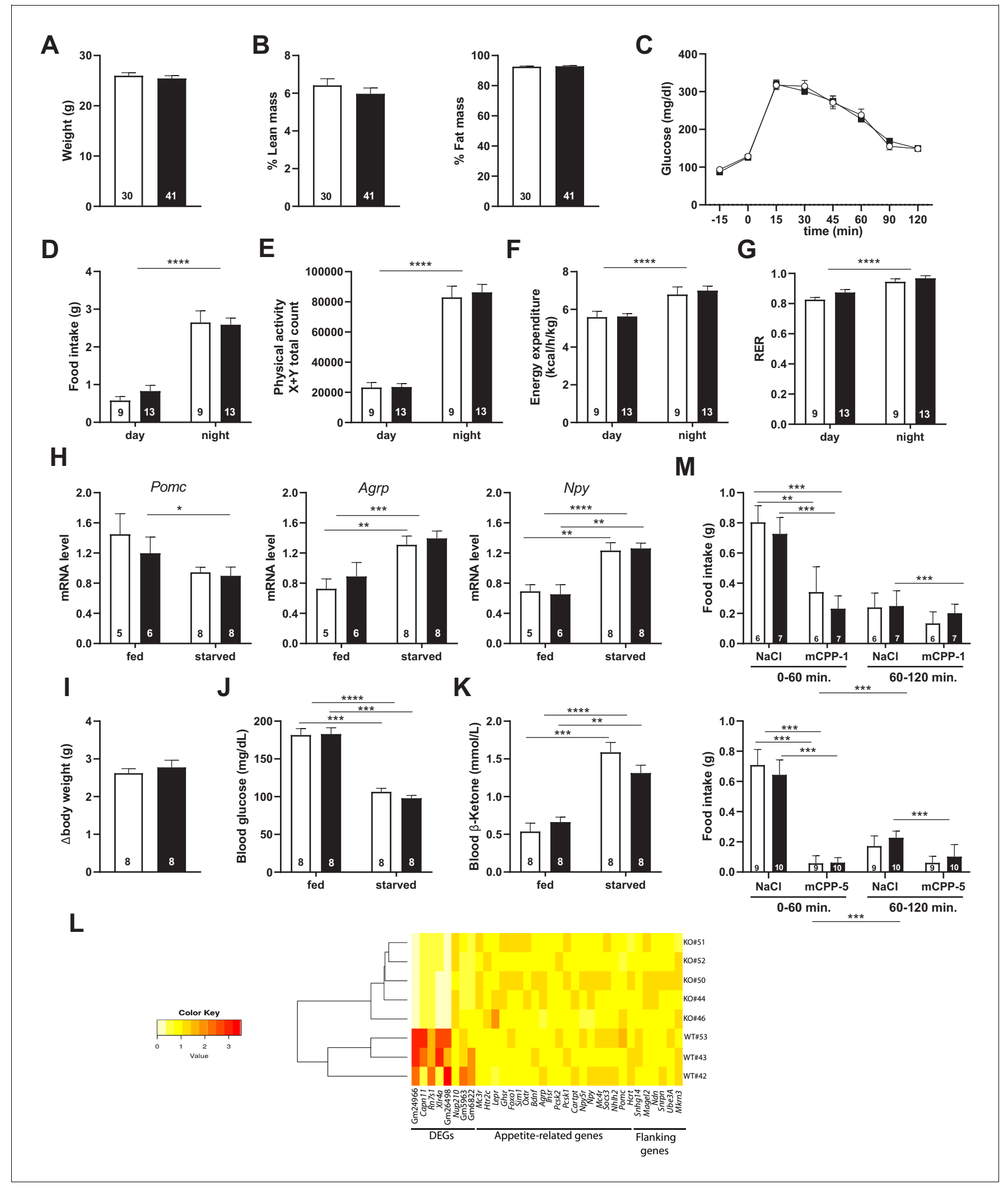

Figure 5. Snord115-deficient mice show regular homeotic feeding behavior and energy balance. Body weight (A) and body composition measured by EchoMRI (B). Glucose tolerance test (GTT) of overnight (16 hr) fasted Snord115-deficient mice ( $n=14)$ and their WT littermates ( $n=9)$ (black and white squares, respectively). The graph represents the fate of glucose versus time after i.p. glucose administration (C). Food intake (D), spontaneous locomotion $(E)$, energy expenditure $(F)$, and respiratory exchange ratio $(G)$ of Snord115-deficient mice and WT littermates were measured using the TSE Figure 5 continued on next page 
Figure 5 continued

PhenoMaster System. (H-K): Snord115-deficient mice and WT littermates were overnight (18 hr) starved. Expression levels of Pomc, Agrp and Npy mRNAs in hypothalamus were measured (RT-qPCR relative to Gapdh) $(\mathrm{H})$. Weight loss after fasting (I), blood glucose $(\mathrm{J})$ and ketone bodies $(\mathrm{K})$ levels were measured in the fed and starved states. (L) Heatmap of the normalized mRNA-seq read counts from a list of genes of interest, as indicated below the panel. The normalized expression for each gene (column) and each genotype (row) is represented by colour code (yellow, lower value; red, higher value). Note that Gm24966 and Gm26498 match the deleted region. (M) Snord115-deficient mice and WT littermates were overnight (16 hr) starved and food intake of $\mathrm{mCPP}$ - and $\mathrm{NaCl}$-treated mice was recorded using the TSE Phenomaster system during the first and second hour after treatment. mCPP was i.p. administered (1 mg/kg, M-top) or ( $5 \mathrm{mg} / \mathrm{kg}$, M-bottom). White and black bars represent WT and Snord115-deficient mice, respectively. The number of individuals analysed are indicated within histograms. None of the analyses in panels A-K and $\mathrm{M}$ showed a significant effect of genotype (ANOVA p-values $>0.05$ for genotype in each panel).

mRNAs were roughly similarly regulated in Snord115-deficient mice during fasting. The overall physiological response to fasting was also unaffected, as evidenced by body weight loss (Figure 5I), decreased glucose levels (Figure 5J) and increased ketone level (Figure 5K). Finally, mRNA-seq also showed that, in the absence of Snord115, global gene expression in hypothalamus of mice fed on regular chow diet is unaffected compared to WT. Indeed, we only uncovered eight differentially expressed transcripts (DEG) with two of them matching the deleted genomic region (supplementary file 3). Hence, the expression of several key appetite-related genes, as well as that of the neighbouring imprinted genes, was in the normal range (Figure $5 \mathrm{~L}$ ). These data suggest that Snord115-deficient mice respond normally to starvation and do not present any apparent defects in hypothalamic gene circuits of the melanocortin pathway.

\section{Snord115-deficient mice respond normally to the appetite-suppressant actions of the HTR2C agonist}

HTR2C is the main, if not the sole, target on which the preferential HTR2C agonist mCPP exerts its appetite-suppressant effects (Berglund et al., 2013; Tecott et al., 1995). We then reasoned that Snord115-deficient mice should display an attenuated mCPP response, that is a decreased sensitivity to the actions of mCPP. Vehicle (saline solution) or mCPP were administrated intra-peritoneally to 16 hr fasted WT and KO mice. Chow diet was then reintroduced $30 \mathrm{~min}$ later and the amount of food consumed was recorded using the TSE Phenomaster system during the first and second hour following food presentation. Figure 5M (upper and lower panels) shows that food intake of $\mathrm{NaCl}$-treated Snord115-deficient mice was similar than that of WT littermates, indicating that homeostatic feeding is normal. This was consistent with unaffected neural circuits of the melanocortin pathway as described above. As expected, food intake of mCPP-treated WT and KO mice was severely and dose-dependent reduced during the first hour as compared to controls $(50 \%$ and $90 \%$ decrease following administration of 1 and $5 \mathrm{mg} / \mathrm{kg}$ of $\mathrm{mCPP}$, respectively). Given that anorectic responses of $\mathrm{mCPP}$ remained in the same range in both genotypes, loss of Snord115 does not perceptibly disturb the hypothalamic HTR2C signaling cascade in vivo, at least when fast-induced food intake is used as a read-out.

\section{Snord115-deficient mice behave normally upon high-fat diet}

We next asked whether metabolic stressors, such as long-term exposure to high-fat diet (HFD), may reveal deficiencies in feeding behavior and/or energy homeostasis not seen on regular chow diet. A cohort of 8- to 12 week-old adult mutant and WT mice were then subjected to HFD (60\% lipid) for 24 weeks. During the course of diet-induced obesity, body weight gain of Snord115-KO mice was similar to WT mice (Figure 6A) with normal adiposity as evidenced by the weights of perigonadal, subcutaneous fat mass and liver measured after euthanasia. Only brown adipose tissue showed a statistically significant change, with Snord115-KO tissues being 38\% heavier than WT tissues (Figure 6B). We then searched for potential differences in glucose metabolism by performing an oral glucose test tolerance after 12 weeks of HFD exposure. Capability for glucose clearance in Snord115-KO mice did not differ substantially from that of WT littermates (Figure 6C). In addition, indirect calorimetry analyses did not reveal any obvious differences in food intake (Figure 6D), ambulatory activities (Figure 6E), energy expenditure (Figure 6F) or respiratory exchange ratio (Figure 6G). Altogether, our analyses did not unveil significant metabolic differences between Snord115-KO and WT littermates after HFD exposure. 
A

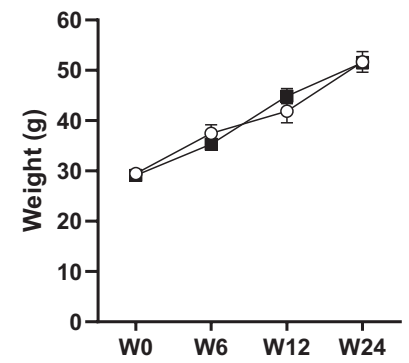

D

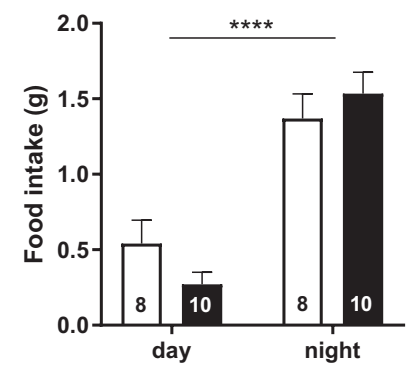

B

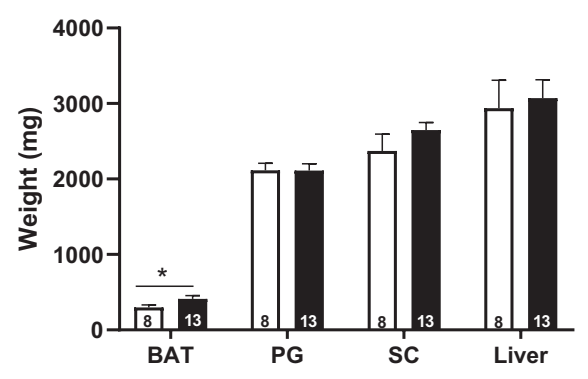

E

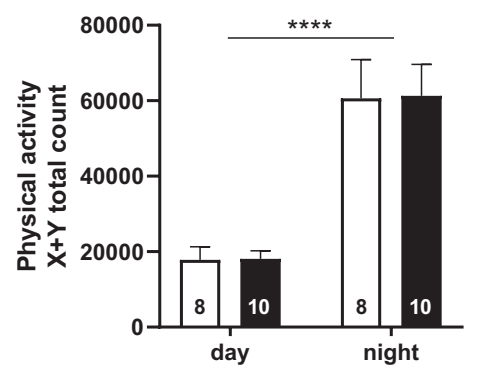

F
C

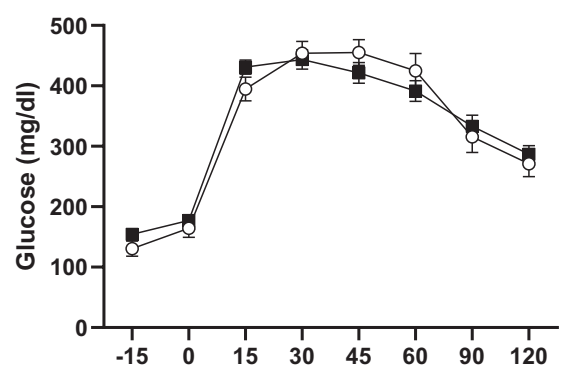

G

Figure 6. Snord115-deficient mice behave normally when fed a high-fat diet. (A) Weight of Snord115-deficient mice and WT littermates before (W0) and after 6 (W6), 12 (W12) and 24 (W24) weeks of HFD. (B) Adiposity of Snord115-deficient mice and WT littermates after 24 weeks of HF diet as judged by the weights of brown adipose tissue (BAT), perigonadal (PG) fat, subcutaneous (SC) fat and liver. (C) Glucose tolerance test of overnight (16 hr) fasted Snord115-deficient $(n=13)$ and WT littermates $(n=8)$ after 12 weeks of HFD. The graph represents the fate of glucose versus time after oral glucose administration (1.5 g/kg). Food intake (D), spontaneous locomotion (E), energy expenditure (F) and respiratory exchange ratio (G) of Snord115deficient mice and WT littermates were measured after 16 weeks of HFD (Phenomaster TSE System). White and black bars represent WT and Snord115deficient mice, respectively. The number of individuals analyzed are indicated within histograms. None of these analyses showed a significant effect of genotype (ANOVA p-values $>0.05$ for genotype in each panel), except for panel B ( $p$-value $=0.04125$ for genotype, with pairwise t-tests indicating a significant difference between WT and KO brown adipose tissues).

\section{Discussion}

In this study, we challenged long-standing observations linking the neuronal-specific SNORD115 genes to activity of the HTR2C receptor and clinical features of PWS. More precisely, we aimed at testing, for the first time and at the organism level, the hypothesis according to which SNORD115 regulates the processing of HTR2C pre-mRNA and, in doing so, influences HTR2C-mediated brain functions. Of particular translational relevance, lack of SNORD115, and thus putative defects in posttranscriptional regulation of HTR2C pre-mRNA could, in principle, account for impaired emotional response and/or food seeking behavior that feature PWS (Cavaillé, 2017; Marty and Cavaillé, 2019; Stamm et al., 2017).

Despite the fact that we thoroughly assessed post-transcriptional regulation of Htr2c pre-mRNA in numerous discrete brain regions collected from a substantial number of genetically comparable WT and Snord115-KO mice, we failed to detect any discernible impact on alternative splicing, as judged by the regular-to-truncated ratio of alternatively spliced Htr2c mRNA isoforms. Furthermore, only subtle changes in regional-specific RNA editing of functional relevance, if any, were uncovered. Our observations are in line with two recent in vivo studies. Reactivation of the Snord116-lpwSnord115 genomic interval in choroid plexus - that does not normally express Snord115 - leads to modest impact on RNA editing without any impairment in alternative splicing of Htr2c pre-mRNA (Raabe et al., 2019). Moreover, oligonucleotides mimicking Snord115 base-pairing have no effects on alternative splicing, despite the fact that in vivo delivery of antisense oligonucleotides targeting 
other RNA segment of $\mathrm{Htr} 2 \mathrm{c}$ pre-mRNA can alter the regular-to-truncated ratio of HTR2C (Zhang et al., 2016). Hence, in vivo molecular outputs of SnoRD115/Htr2c mRNA interaction are more complex than previously inferred from in vitro observations (Kishore and Stamm, 2006; Vitali et al., 2005).

Our findings therefore may appear at odds with prior observations, including our own (Cavaillé et al., 2000; Vitali et al., 2005). These apparent discrepancies deserve to be tempered by considering them in their full scientific context. First, in vitro studies with non-neuronal cells overexpressing both Htr2c and Snord115 from artificial mini-genes do not take into account differential cellular compartmentalization of the two interacting RNA partners (Kishore and Stamm, 2006; Vitali et al., 2005). In addition, it has been shown that 'any cellular RNA' can be modified, at least to some extent, by forced expression of an exogenously expressed SNORD (Cavaillé et al., 1996; Kiss-László et al., 1996). Therefore, in vitro data must be interpreted with caution and, as such, they must be considered as proof-of-principles but by no means as definitive functional proofs. Second, conflicting observations regarding the precise mode of action of Snord115 still remained. Changes in Htr2c alternative splicing were described in the hypothalamus of PWS-IC mice (Garfield et al., 2016) but not in those of PWS patients studied (Bochukova et al., 2018) or in whole brain of PWSIC mice (Doe et al., 2009). Third, although altered Htr2c RNA editing was reported in the brain of PWS-IC and PatDp/+ mouse models, these changes did not correlate with the dosage of Snord115 (Doe et al., 2009; Nakatani et al., 2009). In addition, no reproducible editing changes were noticed in the frontal cortex of a few PWS patients (Glatt-Deeley et al., 2010). Analyses of RNA editing in these studies involved a very small number of sequenced HTR2C cDNA clones, typically $\sim 20-100$ per genotype. Given that the combinatorial RNA editing of the HTR2C pre-mRNA produces 32 mRNA edited isoforms, low-coverage sequencing procedures are subject to strong sampling biases and low statistical power, thus rendering the interpretation of changes in the level of edited HTR2C isoforms highly risky. As already correctly pointed out by others (Abbas et al., 2010; Morabito et al., 2010b; O'Neil and Emeson, 2012), recent high-throughput sequencing methods, as described here with $\sim 1$ million sequences per genotype, have made it feasible to resolve such technical issues. Accordingly, our findings are much more statistically robust than previous published studies. In such a complex framework, demonstrating the presence of a 2'-O-methyl group at the C-site would undoubtedly represent ultimate proofs to define the mode of action of Snord115. However, identifying a ribose methylated nucleotide in low abundance $\mathrm{Htr} 2 \mathrm{c}$ transcripts remains technically challenging, in particular if methylated at sub-stoichiometric levels.

The question then arises as to whether loss of Snord115 is accompanied by physiological abnormalities. Eating disturbance and obesity in PWS (Cassidy et al., 2012), together with the anorectic proprieties of HTR2C (Berglund et al., 2013; D'Agostino et al., 2018; Heisler et al., 2002; Xu et al., 2010; Xu et al., 2008; Zhou et al., 2007), prompted us to first concentrate on food intake and energy balance. Our genetic background and experimental settings, however, failed to reveal any notable alterations on regular diet, upon fasting-refeeding transition or even after exposure to HFD. Of note, blunted feeding effects of the HTR2C agonist (WAY-161503) and impaired melanocortin signaling were described in the PWS-IC mice. These defects were attributed to lack of Snord115 (Garfield et al., 2016). The PWS-IC mouse model carries a paternally inherited deletion of the imprinted center $(\mathrm{IC})$ region leading to the silencing of all imprinted genes positioned on the paternal allele (Yang et al., 1998). Moreover, these knockout mice are growth retarded and it is necessary to switch to a hybrid genetic background to avoid $80-100 \%$ neonatal mortality due to absence of paternal contribution. These inherent limitations represent obvious sources of confounding factors. Thus, we favor an alternative explanation according to which defects in HTR2C-mediated feeding circuitries result from a combination of the deficiencies of several paternally expressed genes. This is all the more likely as defects in the serotonergic system have been described in mice disrupted for the paternally expressed Magel2 (Mercer et al., 2009) or Ndn (Zanella et al., 2008) genes. Moreover, altered expression of neuropeptide of the melanocortin system was also reported in Snord116-KO mice (Burnett et al., 2017; Qi et al., 2016). Thus, Snord115 appears largely dispensable for homeostatic feeding and, as such, it considerably differs from Snord116 ablation which leads to decreased body-weight, apparent increased food intake and resistance to HFD-induced obesity, among other phenotypes (Ding et al., 2008; Polex-Wolf et al., 2018; Qi et al., 2016; Skryabin et al., 2007; reviewed in Marty and Cavaillé, 2019). 
The apparent lack of profound molecular and behavioral consequences does not necessarily mean that Snord115 is of minor relevance. As a case in point, we observed changes in the excitability of 5-HT neuronal circuitries in living Snord115-KO mice (B. Guiard, personal communication). More broadly, the lack of SNORD115 might only have observable phenotypic consequences in sensitized genetic contexts, for example when expression of the other flanking co-regulated paternally expressed genes is also disrupted as observed in the vast majority of PWS people or in PWS-IC mice. Consistent with that possibility, mice simultaneously deleted for Snord115 and Snord116 genes display more severe phenotypes than single Snord115- or Snord116-KO mice (Boursereau, Marty et al. unpublished observations). Finally, and in the same vein, loss of SNORD115 might only become apparent under perturbed metabolic contexts, perhaps as 'secondary disease-effects' once obesity is fully established in individuals with PWS.

There are other limitations commonly known to blur phenotypes in constitutive KO models. An obvious caveat is that any tissues, and especially brain, are composed of heterogeneous cell populations. For instance, transcriptomic analyses of single cells in mouse hypothalamus identified 34 neuronal cell clusters (Chen et al., 2017). Pomc neurons represent a few per cent of these hypothalamic neurons with only 30-40\% expressing Htr2c (Lam et al., 2017). Assuming that Snord115 mostly regulates Htr2c processing in the minority of Pomc neurons, it might then be illusory to hope detecting robust molecular changes in a mixture of molecularly and phenotypically diverse neurons. An additional layer of complexity may also arise from poorly understood 'adaptive mechanisms' which increase the density of the fully edited (VGV) HTR2C receptor at the cell membranes, very likely compensating for its diminished activity (Kawahara et al., 2008; Morabito et al., 2010a; Olaghere da Silva et al., 2010). Finally, how site-specific RNA editing is regulated remains a topic of intense research (Freund et al., 2020 and references therein). Initial studies based on Sanger sequencing methods claimed that $\mathrm{Htr} 2 \mathrm{c}$ editing is dynamically regulated in a context-dependent manner, particularly depending on serotonin levels (Schmauss, 2003). Yet, more recent high-throughput sequencing analyses did not fully confirm all these earlier findings. Only rather subtle RNA editing changes were noticed with respect to genetic background or serotonin content (Abbas et al., 2010; Morabito et al., 2010b), disease states (O'Neil and Emeson, 2012; Zhu et al., 2012), pharmacological manipulations (Abbas et al., 2010) or reovirus infections (Hood et al., 2014). Hence, Htr2c RNA editing appears robustly controlled very likely by distinct overlapping mechanisms and Snord115 might only be one of these regulators. Keeping these potential limitations in mind, future studies involving conditional Snord115 gene deletion together with single neuron analyses are now required to fully apprehend how loss of SNORD115 may shape HTR2C-mediated neuronal functions and thus possibly the pathophysiology of PWS.

\section{Materials and methods}

\section{Mice housing and breeding}

Animal procedures were approved by the University of Toulouse and CNRS Institutional Animal Care Committee (DAP2016061716367988 and DAP2018011214542827). The animal housing facility met CNRS standards. Mice were housed in a temperature-controlled room with a $12 \mathrm{hr}$ light-dark cycler and access to water and food ad libitum, either regular chow diet or HFD diet (ssniff DIO - $60 \mathrm{~kJ} \%$ fat [Lard]). We backcrossed to C57BL/6J genetic background for at least eight generations before proceeding to behavioral and metabolic analyses. Upon euthanasia, tissues were harvested, weighted and immediately snapfrozen in liquid nitrogen and stored at $-80^{\circ} \mathrm{C}$.

\section{Generation of Snord115 knock-out mouse model}

A Snord115 knock-out mouse model was generated by co-injecting zygotes isolated from (C57BL/ 6JxCBA) F1 mice with in vitro transcribed Cas9 encoding mRNA (GeneArt CRISPR nuclease mRNA, Invitrogen) and two guide RNAs (MEGAshortscript T7 Transcription Kit; Ambion) designed to basepair upstream and downstream of Snord115 gene array (crispr.mit.edu tool). Briefly, prepubertale (C57BL/6JxCBA) F1 female (4-6 weeks old) were superovulated by IP injection of 5IU PMS and 5IU hCG at an interval of $46 \mathrm{hr}$ and mated overnight with (C57BL/6JxCBA) F1 adult male mice. Zygotes were collected after $22 \mathrm{hr}$ of hCG injection. Microinjection was performed using an Eppendorf microinjector. Typically, a few picoliters of Cas9 mRNA (100 ng/ $\mu \mathrm{L}$ ) and in vitro transcribed sgRNAs (25 
$\mathrm{ng} / \mu \mathrm{L}$ each) were co-injected into cytoplasm and pronuclei of zygote. Injected zygotes were then cultured in M16 medium until blastocyst stage for analyzing cleavage efficiency or directly transferred into the oviductal ampullas of pseudopregnant female mice (around 20 embryos per female). Following the CRISPR/Cas9 procedure, pups born were selected by PCR on genomic DNA from tail tips (Wizard Genomic DNA Purification Kit; Promega). Primers are listed in Supplementary file 4.

\section{RNA extraction, RT-qPCR, and Northern blot}

Total RNA was extracted using TRI reagent (Euromedex) followed by RNAse free-RQ1 DNAse (Promega) and proteinase K (Sigma) treatments. $1 \mu \mathrm{g}$ of whole cell RNA was reverse transcribed with random hexamer primers using Go Script Reverse Transcriptase kit (Promega) at $42^{\circ} \mathrm{C}$ for 60 min. mRNA expression was performed using the IQ Custom SYBR Green Supermix (Bio-Rad) qPCR. The relative quantification of gene expression was performed using the standard curve method with triplicates for each data point. For Northern blotting analysis, $5 \mu \mathrm{g}$ of total RNA was fractionated by electrophoresis on a $6 \%$ polyacrylamide/7 M urea denaturing gel. Electro transferred onto a nylon membrane (Amersham Hybond-N, GE Healthcare) followed by UV crosslinking (Stratalinker). Hybridizations were carried out with $5^{\prime}$-end ${ }^{32} \mathrm{P}$-labeled-DNA oligonucleotide probes. Membranes were incubated overnight at $50^{\circ} \mathrm{C}$ in $5 X$ SSPE, $5 X$ Denhardt's, $1 \%$ SDS, $150 \mu \mathrm{g} / \mathrm{mL}$ yeast tRNA and washed twice in $0.1 \%$ SSPE, $0.1 \%$ SDS for $15 \mathrm{~min}$ at room temperature. a Typhoon Biomolecular Imager (Amersham) and visualized using Multi Gauge V3.0 software. Radioactive signals were revealed using a Typhoon Biomolecular Imager (Amersham) and visualized using Multi Gauge V3.0 software. Primers are listed in Supplementary file 4.

\section{A-to-I RNA editing analyses}

A 249-nt long segment overlapping the spliced Exon IV-Exon V junction of Htr2c mRNA was amplified with $\mathrm{Htr} 2 \mathrm{c}-\mathrm{F}$ and $\mathrm{Htr} 2 \mathrm{c}-\mathrm{R}$ primers (35 amplification cycles; annealing temperature of $65^{\circ} \mathrm{C}$ ). Single multiplexing was performed using home-made $6 \mathrm{bp}$ index which were added to reverse primer during a second PCR (12 cycles) using forward P5 and reverse P7 primers. Primers are listed in Supplementary file 4. The resulting PCR products were purified and sequenced on a HiSeq3000 (Illumina) according to the manufacturer instructions. The quality of the run was checked internally using PhiX (15\%) and each paired-end sequence was assigned to its sample with the help of the previously integrated index. Reads were aligned on the mm10 mouse genome using hisat2 (Kim et al., 2019) and reads mapping on the amplicon locus were selected using bedtools. For each of the five editing sites, A-to-G conversion was scored in every read with high quality (sequencing quality score $\geq 20$ for the nucleotide mapped on that site). Raw data are available on Sequence Read Archive (SRA) database under the accession numbers PRJNA603261 and PRJNA603264. Scripts used for that analysis, detailed instructions and intermediary data have been deposited at https://github. com/HKeyHKey/Hebras_et_al_2020 (Seitz, 2020; copy archived at swh:1:rev: 1b96b6f5e8d479eb43f12f6687f04d4a60f4e305).

\section{rRNA 2'O-methylation profiling}

RiboMeth-seq was performed in biological triplicates on whole adult mouse brains (Birkedal et al., 2015). In brief, $5 \mu \mathrm{g}$ of total RNA was alkaline degraded and size fractionated to the range of 20-40 nt. Sequencing adaptors were ligated on to the ends of the alkaline degraded RNA using a modified tRNA ligase. The library RNA containing adaptors was reverse transcribed using Superscript IV (Thermo Fisher Scientific). The final libraries were sequenced on a PI Chip v3 (Thermo Fisher Scientific) using an lon Proton semiconductor sequencer. Reads were mapped against curated mouse rRNA sequences (Hebras et al., 2020). RiboMeth-seq data are available on GEO under the accession number GSE145159.

\section{Transcriptomic analyses}

Library preparation (polyA selection) and Illumina sequencing $(2 \times 150$ bp configuration) were performed by Genewiz. Raw data quality control was done using FASTQC (Version 0.11.9). Reads were aligned to reference genome (GRCm38/mm10, Dec. 2011) with STAR (Version 2.4.0.1). Read counts were generated for each annotated gene (GRCm38/mm10, Ensembl gtf release 91) using HTSeqcount (Version 0.11.1). Read normalization and pairwise differential gene expression analysis with 
multiple testing corrections were conducted using the R Bioconductor DESeq2 package (Version 1.26). The heat map was produced by $R$ (heatmap.2) using normalized RNA-seq read counts from a list of genes of interest. Genes reads counts per sample were first normalized by the 'Relative Log Expression' normalization (RLE) implemented in the DESeq2. Each normalized count was then normalized by the mean normalized value of the gene across all samples, in order to remove differences due to the level of expression of each gene. Samples are clustered in the left side of the figure, with a dendrogram, computed with euclidian distance and the complete agglomeration method. Raw data are available on Sequence Read Archive (SRA) database under the accession number PRJNA608249.

\section{Behavioral procedures}

Behavioral tests were conducted as previously described in Marty et al., 2016 and references therein. Most of them were performed blind during the light phase (from 8:30 a.m to 1 p.m.) using 3- to 5-month-old male mice (backcrossed on the C57BL/6J genetic background for $n>8$ generations). Open Field - Locomotion and exploratory behavior were measured in a circular arena (height, $30 \mathrm{~cm}$; diameter, $40 \mathrm{~cm}$ ) located in a room containing no conspicuous features and illuminated by a white light $(20 \mathrm{~lx})$. Time spent in the center of the arena was recorded using the video tracker software (Ethovison XT, Noldus, Netherlands). Locomotion was scored during a 10 min session whereas center vs border activity were only analyzed during the first $5 \mathrm{~min}$. Elevated Plus Maze - Mice were placed in an automated EPM (Imetronic, Pessac, France). This maze consisted of a plus (+)-shaped track with two closed and two open arms $(30 \times 10 \times 20 \mathrm{~cm})$ that extended from a central platform $(10 \times 10 \mathrm{~cm})$. The apparatus was elevated $50 \mathrm{~cm}$ above the floor and was surrounded by a white curtain with no conspicuous cues. Each trial began with the mouse placed in the central zone. The number of entries into the closed and open arms and the time spent in each arm were monitored during the first $5 \mathrm{~min}$. Novelty-Suppressed Feeding - Food-deprived mice for $24 \mathrm{hr}$ were tested in a $50 \times 50 \times 20 \mathrm{~cm}$ box covered with bedding and illuminated by a $70 \mathrm{~W}$ lamp. A single pellet of food was placed on a white paper positioned in the center of the box. All mice were tested individually for $10 \mathrm{~min}$ and the latency time before the mouse ate the pellet was scored as a measure of motivation. Mice that did not eat during the testing period were not included in the analysis. Immediately afterwards, each single mouse returned to its home cage and the amount of food consumed was measured for $5 \mathrm{~min}$ (control for change in appetite as a possible confounding factor). Tail suspension test -Mice were suspended by their tails with tape, such that they cannot escape or hold on to nearby surfaces. The test was performed using the Tail Suspension Test System (BIOSEB) during a 6min session. Immobility time was manually scored as an index of resignation. Forced swim test Mice were introduced individually in a plastic cylinder $(25 \mathrm{~cm}$ tall $\times 18 \mathrm{~cm}$ in diameter) filled with water $\left(23-25^{\circ} \mathrm{C}\right)$ to a depth of $19 \mathrm{~cm}$. A 6-min session was used and immobility time was only scored during the last $4 \mathrm{~min}$. Three-chamber test -Social behavior was measured in a rectangular threechambered enclosure $(60 \times 40 \mathrm{~cm})$ with clear walls $22 \mathrm{~cm}$ high. Removable doors blocked access from the center chamber to the outer chambers. Two cages (diameter $8 \mathrm{~cm}$, height $15 \mathrm{~cm}$ ) were placed in the two outer chambers. On day 1 (5 min habituation session), mice were introduced into the apparatus with two empty cages. On day 2, a stranger mouse (S1) was introduced in one of the two cages and time spent interacting with S1 (sniffing) was measured during a 5 min session. Preference for S1 over the empty cage was used as a measure of sociability. During the second stage (same day), mice were submitted to two consecutive sessions with the same stranger with an intersession resting period of $1 \mathrm{hr}$ during which they were returned to the home-cage. On day 3 , mice were submitted to the social novelty protocol (5-min session), with the previously encountered S1 mouse introduced in one cage and another stranger mouse (S2) was placed in the other cage. Preference for the previously encountered mouse over the familiar one was used as a measure of preference for social novelty.

\section{Determination of basal metabolism by indirect calorimetry}

Indirect calorimetry was performed after $24 \mathrm{hr}$ of acclimatization in individual cages. Oxygen consumption, carbon dioxide production, and food and water intake were measured (Phenomaster; TSE Systems, Bad Homburg v.d.H., Germany) in individual mice at $15 \mathrm{~min}$ intervals during a $24 \mathrm{hr}$ period at constant temperature $\left(22^{\circ} \mathrm{C}\right)$. The respiratory exchange ratio $\left([R E R]=V \mathrm{CO}_{2} / \mathrm{Vo}_{2}\right)$ was measured. 
Energy expenditure (in kcal/day $/ \mathrm{kg}^{0.75}=1.44 \times \mathrm{Vo}_{2} \times[3.815+1.232 \times \mathrm{RER}]$ ), glucose oxidation (in $\left.\mathrm{g} / \mathrm{min} / \mathrm{kg}^{0.75}=\left[\left(4.545 \times V_{\mathrm{CO}_{2}}\right)-\left(3.205 \times V_{\mathrm{O}_{2}}\right)\right] / 1000\right)$ and lipid oxidation (in $\mathrm{g} / \mathrm{min} / \mathrm{kg}^{0.75}=[1.672 \times$ $\left.\left.\left(\mathrm{Vo}_{2}-\mathrm{V}_{\mathrm{co}}\right)\right] / 1000\right)$ were calculated. Ambulatory activities of the mice were monitored by infrared photocell beam interruption (Sedacom; Panlab-Bioseb).

\section{Glucose test tolerance and body composition}

Glucose tolerance test (GTT) was performed under chow diet and at 12 weeks of HFD (i.p. and oral glucose $(1.5 \mathrm{~g} / \mathrm{kg}$ ) administration, respectively) after an overnight fast and blood glucose levels from the tail vein were monitored over time using a glucometer (Accu-Chek). Total body fat and lean mass on chow diet were determined in mice placed in a clear plastic holder, without anaesthesia or sedation, and inserted into the EchoMRI-3-in-1 system (Echo Medical Systems, Houston, TX). Body composition was also evaluated by weighing liver, brown adipose tissue, perigonadal and subcutaneous fat.

\section{In situ hybridization on brain tissues}

RNA FISH experiments were carried out on coronally sectioned 4\% PFA fixed brain tissue $(25 \mu \mathrm{m}$; cryostat) collected from adult Pomc-eGFP transgenic mice (C57BL/6J-Tg(Pomc-EGFP)1Low/J; Jackson Laboratory). Briefly, slides were hybridized overnight at $37^{\circ} \mathrm{C}$ in $15 \%$ formamide, $2 X$ SSPE, $10 \%$ dextran sulfate, $150 \mu \mathrm{g} / \mathrm{mL}$ yeast tRNA and $10 \mathrm{ng}$ of Cy3-labeled SNORD115 oligonucleotide probe (TXGAGCATGAATTTXATGTCATCACCTXTCTTCATGACAXT, with $X=$ Amino-allyl-modified nucleotides). Samples were washed at room temperature in 15\% formamide, 2 X SSPE (20 min, twice), then 1XXSSPE (10 $\mathrm{min})$ and mounted in Moviol DAPI $(0.1 \mathrm{mg} / \mathrm{mL})$. Images were captured with a CoolSnap $\mathrm{HQ}$ camera (Princeton Instruments) mounted on an inverted IX-81 microscope (Olympus) with a 1006 PL APO ON objective (NA 1.4) and the Metavue software.

\section{Statistical methods}

$\mathrm{R}$ and the Graphpad Prism (version 8) statistical software were used for data analysis. For multivariate comparisons, statistical significance of the observed effects was calculated using ANOVA. When ANOVA applicability conditions were not met (variance heterogeneity or non-normality of residuals), measured values were log-transformed. In a few cases (Figure $5 E$ and $F$, the two panels of Figure 5L, Figure 6E and Figure 6G), ANOVA applicability conditions were not fully met even after log-transformation, resulting in imprecise p-value calculation. For time-course analyses, explanatory variables were either genotype and time (Figure 6A) or genotype and a variable depending on time by a bi-exponential function, to account for the non-linearity of glucose concentration upon time (Figures 5C and 6C). Data files and R scripts for these analyses have been deposited on https:// github.com/HkeyHKey/Hebras_et_al_2020 (Seitz,2020; copy archived at swh:1:rev:1b96b6f5e8d479eb43f12f6687f04d4a60f4e305). For post-hoc tests and for univariate comparisons with two groups, significance was assessed using Student's t-test, or using the Mann-Whitney test when experimental values were not normally distributed. Data are presented as mean $\pm \mathrm{SEM}$ and statistically significant differences are indicated as ${ }^{\star} p<0.05,{ }^{\star \star} p<0.01,{ }^{\star \star *} p<0.001$ and ${ }^{\star \star \star *} p<0.0001$.

\section{Acknowledgements}

We thank the ABC Facility of ANEXPLO Toulouse for the mouse husbandry. We are grateful to the GeT core facility, Toulouse, France (get@genotoul.fr) and the Phenotypage service - US006/CREFRE INSERM/UPS. We are particularly indebted to Sophie Le Gonidec, Pauline Heuillard and Camille Eché for their technical assistance and scientific support. The authors also acknowledge «the Mouse Behavioral Core» (Center of Integrative Biology, Toulouse), notably Sébastien Lopez for his advices in setting up behavioral apparatus and procedures. We thank Xavier Fioramonti for the gift of PFAfixed brains dissected from Pomc-eGFP transgenic mice. We also thank $G$ Canal for assistance in the high-throughput analysis of A-to-I RNA editing. This work was supported by the 'Fondation pour la Recherche Médicale' (FRM; DEQ20160334936), the Agence Nationale de la Recherche (ANR-18CE12-0008-01) and the Fundation for Prader-Willi Research (FPWR). J Hebras is grateful to the 'La ligue Nationale contre le Cancer' for the 4th year PhD funding. 


\section{Additional information}

\begin{tabular}{lll}
$\begin{array}{l}\text { Funding } \\
\text { Funder }\end{array}$ & Grant reference number & Author \\
\hline $\begin{array}{l}\text { Foundation for Prader-Willi } \\
\text { Research }\end{array}$ & Jérôme Cavaille \\
\hline $\begin{array}{l}\text { Fondation pour la Recherche } \\
\text { Médicale }\end{array}$ & DEQ20160334936 & Jérôme Cavaille \\
\hline $\begin{array}{l}\text { Agence Nationale de la Re- } \\
\text { cherche }\end{array}$ & ANR-18-CE12-0008-01 & Jérôme Cavaille \\
& &
\end{tabular}

The funders had no role in study design, data collection and interpretation, or the decision to submit the work for publication.

Author contributions

Jade Hebras, Conceptualization, Formal analysis, Validation, Investigation, Writing - review and editing; Virginie Marty, Formal analysis, Validation, Investigation, Writing - review and editing; Jean Personnaz, Pascale Mercier, Nicolai Krogh, Formal analysis, Investigation, Writing - review and editing; Henrik Nielsen, Supervision, Writing - review and editing; Marion Aguirrebengoa, Resources, Data curation, Software, Visualization, Writing - review and editing; Hervé Seitz, Conceptualization, Resources, Data curation, Software, Validation, Visualization, Writing - review and editing; Jean-Phillipe Pradere, Formal analysis, Supervision, Investigation, Writing - review and editing; Bruno P Guiard, Formal analysis, Supervision, Writing - review and editing; Jérôme Cavaille, Conceptualization, Supervision, Funding acquisition, Writing - original draft, Project administration, Writing review and editing

Author ORCIDs

Jean Personnaz (iD) http://orcid.org/0000-0001-6447-780X

Nicolai Krogh (iD) https://orcid.org/0000-0001-8870-7091

Henrik Nielsen (iD https://orcid.org/0000-0001-7143-2810

Hervé Seitz (D) http://orcid.org/0000-0001-8172-5393

Jérôme Cavaille (iD https://orcid.org/0000-0003-2833-6836

Ethics

Animal experimentation: Animal procedures were approved by the University of Toulouse and CNRS Institutional Animal Care Committee (DAP2016061716367988 and DAP2018011214542827). The animal housing facility met CNRS standards.

Decision letter and Author response

Decision letter https://doi.org/10.7554/eLife.60862.sa1

Author response https://doi.org/10.7554/eLife.60862.sa2

\section{Additional files}

Supplementary files

- Supplementary file 1. RiboMeth-seq scores and statistics. Raw data are deposited at NCBI Gene Expression Omnibus (GEO) and accessible through GSE145159. Note that RiboMeth-seq data from WT littermates were also included in Hebras et al., 2020 RNA biol.

- Supplementary file 2. Snord115 is expressed in pro-opiomelanocortin (Pomc) neurons in the arcuate nucleus of the hypothalamus. Coronally sectioned brain tissues of adult Pomc-eGFP transgenic mice (Pomc neurons appear green in the merge) were hybridized with Cy3-labeled DNA oligonucleotides (red signals in the merge). Bottom: Snord115 signals are detected in nuclear regions poorly stained by DAPI (white arrow), very likely representing nucleoli. 
- Supplementary file 3. Changes in transcript steady-state levels in the adult hypothalamus of Snord115-deficient mice relative to WT littermates (mRNA-seq). Raw data are available on Sequence Read Archive (SRA) database under the accession number PRJNA608249.

- Supplementary file 4. Sequences of DNA oligonucleotides used in the study.

- Transparent reporting form

Data availability

RiboMeth-seq data are available on GEO under the accession number GSE145159 Raw data (mRNAseq) are available on Sequence Read Archive (SRA) database under the accession number PRJNA608249. Raw data (A-to-I RNA editing) are available on Sequence Read Archive (SRA) database under the accession numbers PRJNA603261 and PRJNA603264. Scripts used for that analysis, detailed instructions and intermediary data have been deposited at https://github.com/HKeyHKey/ Hebras_et_al_2020 (copy archived at https://archive.softwareheritage.org/swh:1:rev:1b96b6f5e8d479eb43f12f6687f04d4a60f4e305/).

The following datasets were generated:

\begin{tabular}{|c|c|c|c|c|}
\hline Author(s) & Year & Dataset title & Dataset URL & $\begin{array}{l}\text { Database and } \\
\text { Identifier }\end{array}$ \\
\hline $\begin{array}{l}\text { Hebras J, Marty V, } \\
\text { Personnaz J, Mer- } \\
\text { cier P, Krogh N, } \\
\text { Nielsen H, Aguirre- } \\
\text { bengoa M, Seitz H, } \\
\text { Pradère J-P, Guiard } \\
\text { BP, Cavaillé J }\end{array}$ & 2020 & $\begin{array}{l}\text { Re-assessment of the involvement } \\
\text { of Snord } 115 \text { in the serotonin } 2 \mathrm{C} \\
\text { receptor pathway in a genetically } \\
\text { relevant mouse model }\end{array}$ & $\begin{array}{l}\text { http://www.ncbi.nlm.nih. } \\
\text { gov/geo/query/acc.cgi? } \\
\text { acc=GSE145159 }\end{array}$ & $\begin{array}{l}\text { NCBI Gene } \\
\text { Expression Omnibus, } \\
\text { GSE145159 }\end{array}$ \\
\hline $\begin{array}{l}\text { Hebras J, Marty V, } \\
\text { Personnaz J, Mer- } \\
\text { cier P, Krogh N, } \\
\text { Nielsen H, Aguirre- } \\
\text { bengoa M, Seitz H, } \\
\text { Pradère J-P, Guiard } \\
\text { BP, Cavaillé J }\end{array}$ & 2020 & $\begin{array}{l}\text { Measurement of A-to-I editing in } \\
\text { various adult mouse brain areas in } \\
\text { SNORD115-expressing and } \\
\text { SNORD115-deficient specimens }\end{array}$ & $\begin{array}{l}\text { https://www.ncbi.nlm. } \\
\text { nih.gov/bioproject/ } \\
\text { PRJNA603261 }\end{array}$ & $\begin{array}{l}\text { NCBI BioProject, } \\
\text { PRJNA603261 }\end{array}$ \\
\hline $\begin{array}{l}\text { Hebras J, Marty V, } \\
\text { Personnaz J, Mer- } \\
\text { cier P, Krogh N, } \\
\text { Nielsen H, Aguirre- } \\
\text { bengoa M, Seitz H, } \\
\text { Pradère J-P, Guiard } \\
\text { BP, Cavaillé J }\end{array}$ & 2020 & $\begin{array}{l}\text { Measurement of A-to-I editing in } \\
\text { various embryonic, neonate and } \\
\text { adult mouse brain areas in } \\
\text { SNORD115-expressing and } \\
\text { SNORD115-deficient specimens }\end{array}$ & $\begin{array}{l}\text { https://www.ncbi.nlm. } \\
\text { nih.gov/bioproject/ } \\
\text { PRJNA603264 }\end{array}$ & $\begin{array}{l}\text { NCBI BioProject, } \\
\text { PRJNA603264 }\end{array}$ \\
\hline $\begin{array}{l}\text { Hebras J, Marty V, } \\
\text { Personnaz J, Mer- } \\
\text { cier P, Krogh N, } \\
\text { Nielsen H, Aguirre- } \\
\text { bengoa M, Seitz H, } \\
\text { Pradère J-P, Guiard } \\
\text { BP, Cavaillé J }\end{array}$ & 2020 & $\begin{array}{l}\text { Re-assessment of the involvement } \\
\text { of SNORD115 in the serotonin 2C } \\
\text { receptor pathway in a genetically } \\
\text { relevant model in vivo }\end{array}$ & $\begin{array}{l}\text { https://www.ncbi.nlm. } \\
\text { nih.gov/bioproject/ } \\
\text { PRJNA608249 }\end{array}$ & $\begin{array}{l}\text { NCBI BioProject, } \\
\text { PRJNA608249 }\end{array}$ \\
\hline
\end{tabular}

\section{References}

Abbas Al, Urban DJ, Jensen NH, Farrell MS, Kroeze WK, Mieczkowski P, Wang Z, Roth BL. 2010. Assessing serotonin receptor mRNA editing frequency by a novel ultra high-throughput sequencing method. Nucleic Acids Research 38:e118. DOI: https://doi.org/10.1093/nar/gkq107, PMID: 20185571

Baldini G, Phelan KD. 2019. The melanocortin pathway and control of appetite-progress and therapeutic implications. Journal of Endocrinology 241:R1-R33. DOI: https://doi.org/10.1530/JOE-18-0596, PMID: 30 812013

Berg KA, Cropper JD, Niswender CM, Sanders-Bush E, Emeson RB, Clarke WP. 2001. RNA-editing of the 5-HT (2C) receptor alters agonist-receptor-effector coupling specificity. British Journal of Pharmacology 134:386392. DOI: https://doi.org/10.1038/sj.bjp.0704255, PMID: 11564657

Berglund ED, Liu C, Sohn JW, Liu T, Kim MH, Lee CE, Vianna CR, Williams KW, Xu Y, Elmquist JK. 2013. Serotonin $2 \mathrm{C}$ receptors in pro-opiomelanocortin neurons regulate energy and glucose homeostasis. Journal of Clinical Investigation 123:5061-5070. DOI: https://doi.org/10.1172/JCI70338, PMID: 24177424 
Bervini S, Herzog H. 2013. Mouse models of Prader-Willi syndrome: a systematic review. Frontiers in Neuroendocrinology 34:107-119. DOI: https://doi.org/10.1016/j.yfrne.2013.01.002, PMID: 23391702

Bieth E, Eddiry S, Gaston V, Lorenzini F, Buffet A, Conte Auriol F, Molinas C, Cailley D, Rooryck C, Arveiler B, Cavaillé J, Salles JP, Tauber M. 2015. Highly restricted deletion of the SNORD116 region is implicated in Prader-Willi syndrome. European Journal of Human Genetics 23:252-255. DOI: https://doi.org/10.1038/ejhg. 2014.103, PMID: 24916642

Birkedal U, Christensen-Dalsgaard M, Krogh N, Sabarinathan R, Gorodkin J, Nielsen H. 2015. Profiling of ribose methylations in RNA by high-throughput sequencing. Angewandte Chemie 54:451-455. DOI: https://doi.org/ 10.1002/anie.201408362, PMID: 25417815

Bochukova EG, Lawler K, Croizier S, Keogh JM, Patel N, Strohbehn G, Lo KK, Humphrey J, Hokken-Koelega A, Damen L, Donze S, Bouret SG, Plagnol V, Faroogi IS. 2018. A transcriptomic signature of the hypothalamic response to fasting and BDNF deficiency in Prader-Willi syndrome. Cell Reports 22:3401-3408. DOI: https:// doi.org/10.1016/j.celrep.2018.03.018, PMID: 29590610

Bortolin-Cavaillé ML, Cavaillé J. 2012. The SNORD115 (H/MBII-52) and SNORD116 (H/MBII-85) gene clusters at the imprinted Prader-Willi locus generate canonical box C/D snoRNAs. Nucleic Acids Research 40:6800-6807. DOI: https://doi.org/10.1093/nar/gks321, PMID: 22495932

Bratkovič T, Božič J, Rogelj B. 2020. Functional diversity of small nucleolar RNAs. Nucleic Acids Research 48 : 1627-1651. DOI: https://doi.org/10.1093/nar/gkz1140, PMID: 31828325

Buiting K. 2010. Prader-Willi syndrome and angelman syndrome. American Journal of Medical Genetics Part C: Seminars in Medical Genetics 154C:365-376. DOI: https://doi.org/10.1002/ajmg.c.30273

Bürger J, Horn D, Tönnies H, Neitzel H, Reis A. 2002. Familial interstitial 570 kbp deletion of the UBE3A gene region causing angelman syndrome but not Prader-Willi syndrome. American Journal of Medical Genetics 111: 233-237. DOl: https://doi.org/10.1002/ajmg.10498, PMID: 12210318

Burnett LC, LeDuc CA, Sulsona CR, Paull D, Rausch R, Eddiry S, Carli JF, Morabito MV, Skowronski AA, Hubner G, Zimmer M, Wang L, Day R, Levy B, Fennoy I, Dubern B, Poitou C, Clement K, Butler MG, Rosenbaum M, et al. 2017. Deficiency in prohormone convertase PC1 impairs prohormone processing in Prader-Willi syndrome. Journal of Clinical Investigation 127:293-305. DOI: https://doi.org/10.1172/JCI88648, PMID: 27 941249

Burns CM, Chu H, Rueter SM, Hutchinson LK, Canton H, Sanders-Bush E, Emeson RB. 1997. Regulation of serotonin-2C receptor G-protein coupling by RNA editing. Nature 387:303-308. DOI: https://doi.org/10.1038/ 387303a0, PMID: 9153397

Butler MG, Miller JL, Forster JL. 2019. Prader-Willi syndrome - Clinical genetics, diagnosis and treatment approaches: an update. Current Pediatric Reviews 15:207-244. DOI: https://doi.org/10.2174/ 1573396315666190716120925, PMID: 31333129

Canton H, Emeson RB, Barker EL, Backstrom JR, Lu JT, Chang MS, Sanders-Bush E. 1996. Identification, molecular cloning, and distribution of a short variant of the 5-hydroxytryptamine $2 \mathrm{C}$ receptor produced by alternative splicing. Molecular Pharmacology 50:799-807. PMID: 8863824

Cassidy SB, Schwartz S, Miller JL, Driscoll DJ. 2012. Prader-Willi syndrome. Genetics in Medicine 14:10-26. DOI: https://doi.org/10.1038/gim.0b013e31822bead0, PMID: 22237428

Cavaillé J, Nicoloso M, Bachellerie JP. 1996. Targeted ribose methylation of RNA in vivo directed by tailored antisense RNA guides. Nature 383:732-735. DOI: https://doi.org/10.1038/383732a0, PMID: 8878486

Cavaillé J, Buiting K, Kiefmann M, Lalande M, Brannan Cl, Horsthemke B, Bachellerie JP, Brosius J, Hüttenhofer A. 2000. Identification of brain-specific and imprinted small nucleolar RNA genes exhibiting an unusual genomic organization. PNAS 97:14311-14316. DOI: https://doi.org/10.1073/pnas.250426397, PMID: 11106375

Cavaillé J. 2017. Box C/D small nucleolar RNA genes and the Prader-Willi syndrome: a complex interplay. Wiley Interdisciplinary Reviews: RNA 8:e1417. DOI: https://doi.org/10.1002/wrna.1417

Chagraoui A, Thibaut F, Skiba M, Thuillez C, Bourin M. 2016. 5-HT2C receptors in psychiatric disorders: a review. Progress in Neuro-Psychopharmacology and Biological Psychiatry 66:120-135. DOl: https://doi.org/10.1016/j. pnpbp.2015.12.006, PMID: 26739950

Chen R, Wu X, Jiang L, Zhang Y. 2017. Single-Cell RNA-Seq reveals hypothalamic cell diversity. Cell Reports 18: 3227-3241. DOI: https://doi.org/10.1016/j.celrep.2017.03.004, PMID: 28355573

D'Agostino G, Lyons D, Cristiano C, Lettieri M, Olarte-Sanchez C, Burke LK, Greenwald-Yarnell M, Cansell C, Doslikova B, Georgescu T, Martinez de Morentin PB, Myers MG, Rochford JJ, Heisler LK. 2018. Nucleus of the solitary tract serotonin 5- $\mathrm{HT}_{2 \mathrm{C}}$ Receptors Modulate Food Intake. Cell Metabolism 28:619-630. DOI: https://doi. org/10.1016/j.cmet.2018.07.017, PMID: 30146485

Davies JR, Wilkinson LS, Isles AR, Humby T. 2019. Prader-Willi syndrome imprinting centre deletion mice have impaired baseline and 5-HT2CR-mediated response inhibition. Human Molecular Genetics 28::3013-3023. DOI: https://doi.org/10.1093/hmg/ddz100

de Smith AJ, Purmann C, Walters RG, Ellis RJ, Holder SE, Van Haelst MM, Brady AF, Fairbrother UL, Dattani M, Keogh JM, Henning E, Yeo GS, O'Rahilly S, Froguel P, Farooqi IS, Blakemore Al. 2009. A deletion of the HBII85 class of small nucleolar RNAs (snoRNAs) is associated with hyperphagia, obesity and hypogonadism. Human Molecular Genetics 18:3257-3265. DOI: https://doi.org/10.1093/hmg/ddp263, PMID: 19498035

Ding F, Li HH, Zhang S, Solomon NM, Camper SA, Cohen P, Francke U. 2008. SnoRNA Snord116 (Pwcr1/MBII85) deletion causes growth deficiency and hyperphagia in mice. PLOS ONE 3:e1709. DOI: https://doi.org/10. 1371/journal.pone.0001709, PMID: 18320030

Doe CM, Relkovic D, Garfield AS, Dalley JW, Theobald DE, Humby T, Wilkinson LS, Isles AR. 2009. Loss of the imprinted snoRNA mbii-52 leads to increased 5 htr2c pre-RNA editing and altered 5HT2CR-mediated 
behaviour. Human Molecular Genetics 18:2140-2148. DOI: https://doi.org/10.1093/hmg/ddp137, PMID: 1 9304781

Duker AL, Ballif BC, Bawle EV, Person RE, Mahadevan S, Alliman S, Thompson R, Traylor R, Bejjani BA, Shaffer LG, Rosenfeld JA, Lamb AN, Sahoo T. 2010. Paternally inherited microdeletion at $15 q 11.2$ confirms a significant role for the SNORD116 C/D box snoRNA cluster in Prader-Willi syndrome. European Journal of Human Genetics 18:1196-1201. DOI: https://doi.org/10.1038/ejhg.2010.102, PMID: 20588305

Fitzgerald LW, lyer G, Conklin DS, Krause CM, Marshall A, Patterson JP, Tran DP, Jonak GJ, Hartig PR. 1999. Messenger RNA editing of the human serotonin 5-HT2C receptor. Neuropsychopharmacology 21:82S-90. DOI: https://doi.org/10.1016/S0893-133X(99)00004-4, PMID: 10432493

Fontana P, Grasso M, Acquaviva F, Gennaro E, Galli ML, Falco M, Scarano F, Scarano G, Lonardo F. 2017. SNORD116 deletions cause Prader-Willi syndrome with a mild phenotype and macrocephaly. Clinical Genetics 92:440-443. DOI: https://doi.org/10.1111/cge.13005, PMID: 28266014

Freund EC, Sapiro AL, Li Q, Linder S, Moresco JJ, Yates JR, Li JB. 2020. Unbiased identification of trans regulators of ADAR and A-to-I RNA editing. Cell Reports 31:107656. DOI: https://doi.org/10.1016/j.celrep. 2020.107656, PMID: 32433965

Ganot P, Jády BE, Bortolin ML, Darzacq X, Kiss T. 1999. Nucleolar factors direct the 2'-O-ribose methylation and pseudouridylation of U6 spliceosomal RNA. Molecular and Cellular Biology 19:6906-6917. DOI: https://doi. org/10.1128/MCB.19.10.6906, PMID: 10490628

Garfield AS, Davies JR, Burke LK, Furby HV, Wilkinson LS, Heisler LK, Isles AR. 2016. Increased alternate splicing of $\mathrm{Htr} 2 \mathrm{c}$ in a mouse model for Prader-Willi syndrome leads disruption of $5 \mathrm{HT} 2 \mathrm{C}$ receptor mediated appetite. Molecular Brain 9:95. DOI: https://doi.org/10.1186/s13041-016-0277-4, PMID: 27931246

Glatt-Deeley H, Bancescu DL, Lalande M. 2010. Prader-Willi syndrome, Snord115, and Htr2c editing Neurogenetics 11:143-144. DOI: https://doi.org/10.1007/s10048-009-0209-x, PMID: 19653017

Hebras J, Krogh N, Marty V, Nielsen H, Cavaillé J. 2020. Developmental changes of rRNA ribose methylations in the mouse. RNA Biology 17:150-164. DOI: https://doi.org/10.1080/15476286.2019.1670598, PMID: 31566069

Heisler LK, Cowley MA, Tecott LH, Fan W, Low MJ, Smart JL, Rubinstein M, Tatro JB, Marcus JN, Holstege H, Lee CE, Cone RD, Elmquist JK. 2002. Activation of central melanocortin pathways by fenfluramine. Science 297:609-611. DOI: https://doi.org/10.1126/science.1072327, PMID: 12142539

Heisler LK, Zhou L, Bajwa P, Hsu J, Tecott LH. 2007. Serotonin 5-HT(2C) receptors regulate anxiety-like behavior. Genes, Brain, and Behavior 6:491-496. DOI: https://doi.org/10.1111/j.1601-183X.2007.00316.x, PMID: 17451451

Henry FE, Sugino K, Tozer A, Branco T, Sternson SM. 2015. Cell type-specific transcriptomics of hypothalamic energy-sensing neuron responses to weight-loss. eLife 4:e09800. DOI: https://doi.org/10.7554/eLife.09800

Hood JL, Morabito MV, Martinez CR, Gilbert JA, Ferrick EA, Ayers GD, Chappell JD, Dermody TS, Emeson RB. 2014. Reovirus-mediated induction of ADAR1 (p150) minimally alters RNA editing patterns in discrete brain regions. Molecular and Cellular Neuroscience 61:97-109. DOI: https://doi.org/10.1016/j.mcn.2014.06.001, PMID: 24906008

Kawahara Y, Grimberg A, Teegarden S, Mombereau C, Liu S, Bale TL, Blendy JA, Nishikura K. 2008. Dysregulated editing of serotonin $2 \mathrm{C}$ receptor mRNAs results in energy dissipation and loss of fat mass. Journal of Neuroscience 28:12834-12844. DOI: https://doi.org/10.1523/JNEUROSCI.3896-08.2008, PMID: 1 9036977

Kim D, Paggi JM, Park C, Bennett C, Salzberg SL. 2019. Graph-based genome alignment and genotyping with HISAT2 and HISAT-genotype. Nature Biotechnology 37:907-915. DOI: https://doi.org/10.1038/s41587-0190201-4, PMID: 31375807

Kishore S, Stamm S. 2006. The snoRNA HBII-52 regulates alternative splicing of the serotonin receptor $2 \mathrm{C}$. Science 311:230-232. DOI: https://doi.org/10.1126/science.1118265, PMID: 16357227

Kiss-László Z, Henry Y, Bachellerie JP, Caizergues-Ferrer M, Kiss T. 1996. Site-specific ribose methylation of preribosomal RNA: a novel function for small nucleolar RNAs. Cell 85:1077-1088. DOI: https://doi.org/10. 1016/S0092-8674(00)81308-2, PMID: 8674114

Krogh N, Jansson MD, Häfner SJ, Tehler D, Birkedal U, Christensen-Dalsgaard M, Lund AH, Nielsen H. 2016. Profiling of 2'-O-Me in human rRNA reveals a subset of fractionally modified positions and provides evidence for ribosome heterogeneity. Nucleic Acids Research 44:7884-7895. DOI: https://doi.org/10.1093/nar/gkw482, PMID: 27257078

Lam BYH, Cimino I, Polex-Wolf J, Nicole Kohnke S, Rimmington D, lyemere V, Heeley N, Cossetti C, Schulte R, Saraiva LR, Logan DW, Blouet C, O'Rahilly S, Coll AP, Yeo GSH. 2017. Heterogeneity of hypothalamic proopiomelanocortin-expressing neurons revealed by single-cell RNA sequencing. Molecular Metabolism 6:383392. DOI: https://doi.org/10.1016/j.molmet.2017.02.007, PMID: 28462073

Martin CB, Ramond F, Farrington DT, Aguiar AS, Chevarin C, Berthiau AS, Caussanel S, Lanfumey L, HerrickDavis K, Hamon M, Madjar JJ, Mongeau R. 2013. RNA splicing and editing modulation of 5-HT(2C) receptor function: relevance to anxiety and aggression in VGV mice. Molecular Psychiatry 18:656-665. DOI: https://doi. org/10.1038/mp.2012.171, PMID: 23247076

Marty V, Labialle S, Bortolin-Cavaillé ML, Ferreira De Medeiros G, Moisan MP, Florian C, Cavaillé J. 2016. Deletion of the miR-379/miR-410 gene cluster at the imprinted Dlk1-Dio3 locus enhances anxiety-related behaviour. Human Molecular Genetics 25:728-739. DOI: https://doi.org/10.1093/hmg/ddv510, PMID: 26744330

Marty V, Cavaillé J. 2019. Imprinted small noncoding RNA genes in brain function and behaviour. Current Opinion in Behavioral Sciences 25:8-14. DOI: https://doi.org/10.1016/j.cobeha.2018.05.009 
Mercer RE, Kwolek EM, Bischof JM, van Eede M, Henkelman RM, Wevrick R. 2009. Regionally reduced brain volume, altered serotonin neurochemistry, and abnormal behavior in mice null for the circadian rhythm output gene Magel2 . American Journal of Medical Genetics Part B: Neuropsychiatric Genetics 150B:1085-1099. DOI: https://doi.org/10.1002/ajmg.b.30934

Mombereau C, Kawahara Y, Gundersen BB, Nishikura K, Blendy JA. 2010. Functional relevance of serotonin 2C receptor mRNA editing in antidepressant- and anxiety-like behaviors. Neuropharmacology 59:468-473. DOI: https://doi.org/10.1016/j.neuropharm.2010.06.009, PMID: 20624407

Morabito MV, Abbas Al, Hood JL, Kesterson RA, Jacobs MM, Kump DS, Hachey DL, Roth BL, Emeson RB. 2010a. Mice with altered serotonin 2C receptor RNA editing display characteristics of Prader-Willi syndrome. Neurobiology of Disease 39:169-180. DOI: https://doi.org/10.1016/j.nbd.2010.04.004

Morabito MV, Ulbricht RJ, O'Neil RT, Airey DC, Lu P, Zhang B, Wang L, Emeson RB. 2010b. High-throughput multiplexed transcript analysis yields enhanced resolution of 5-hydroxytryptamine $2 \mathrm{C}$ receptor mRNA editing profiles. Molecular Pharmacology 77:895-902. DOI: https://doi.org/10.1124/mol.109.061903, PMID: 20181818

Muscogiuri G, Formoso G, Pugliese G, Ruggeri RM, Scarano E, Colao A, on behalf of RESTARE. 2019. PraderWilli syndrome: an uptodate on endocrine and metabolic complications. Reviews in Endocrine and Metabolic Disorders 20:239-250. DOI: https://doi.org/10.1007/s11154-019-09502-2, PMID: 31065942

Nakatani J, Tamada K, Hatanaka F, Ise S, Ohta H, Inoue K, Tomonaga S, Watanabe Y, Chung YJ, Banerjee R, Iwamoto K, Kato T, Okazawa M, Yamauchi K, Tanda K, Takao K, Miyakawa T, Bradley A, Takumi T. 2009. Abnormal behavior in a chromosome-engineered mouse model for human 15q11-13 duplication seen in autism. Cell 137:1235-1246. DOI: https://doi.org/10.1016/j.cell.2009.04.024, PMID: 19563756

Niswender CM, Copeland SC, Herrick-Davis K, Emeson RB, Sanders-Bush E. 1999. RNA editing of the human serotonin 5-hydroxytryptamine $2 \mathrm{C}$ receptor silences constitutive activity. Journal of Biological Chemistry 274: 9472-9478. DOI: https://doi.org/10.1074/jbc.274.14.9472, PMID: 10092629

Nonogaki K, Strack AM, Dallman MF, Tecott LH. 1998. Leptin-independent hyperphagia and type 2 diabetes in mice with a mutated serotonin 5-HT2C receptor gene. Nature Medicine 4:1152-1156. DOI: https://doi.org/10. 1038/2647, PMID: 9771748

O'Neil RT, Emeson RB. 2012. Quantitative analysis of $5 \mathrm{ht}(2 \mathrm{C})$ receptor RNA editing patterns in psychiatric disorders. Neurobiology of Disease 45:8-13. DOI: https://doi.org/10.1016/j.nbd.2011.08.026, PMID: 21914481

Olaghere da Silva UB, Morabito MV, Canal CE, Airey DC, Emeson RB, Sanders-Bush E. 2010. Impact of RNA editing on functions of the serotonin $2 \mathrm{C}$ receptor in vivo. Frontiers in Neuroscience 4:26. DOI: https://doi.org/ 10.3389/neuro.23.001.2010, PMID: 20582266

Polex-Wolf J, Lam BY, Larder R, Tadross J, Rimmington D, Bosch F, Cenzano VJ, Ayuso E, Ma MK, Rainbow K, Coll AP, O'Rahilly S, Yeo GS. 2018. Hypothalamic loss of Snord116 recapitulates the hyperphagia of PraderWilli syndrome. Journal of Clinical Investigation 128:960-969. DOI: https://doi.org/10.1172/JCI97007, PMID: 2 9376887

Qi Y, Purtell L, Fu M, Lee NJ, Aepler J, Zhang L, Loh K, Enriquez RF, Baldock PA, Zolotukhin S, Campbell LV, Herzog H. 2016. Snord116 is critical in the regulation of food intake and body weight. Scientific Reports 6: 18614. DOI: https://doi.org/10.1038/srep18614, PMID: 26726071

Raabe CA, Voss R, Kummerfeld DM, Brosius J, Galiveti CR, Wolters A, Seggewiss J, Huge A, Skryabin BV, Rozhdestvensky TS. 2019. Ectopic expression of Snord115 in choroid plexus interferes with editing but not splicing of 5-Ht2c receptor pre-mRNA in mice. Scientific Reports 9:4300. DOI: https://doi.org/10.1038/s41598019-39940-6, PMID: 30862860

Runte M, Varon R, Horn D, Horsthemke B, Buiting K. 2005. Exclusion of the C/D box snoRNA gene cluster HBII52 from a major role in Prader-Willi syndrome. Human Genetics 116:228-230. DOI: https://doi.org/10.1007/ s00439-004-1219-2, PMID: 15565282

Sahoo T, del Gaudio D, German JR, Shinawi M, Peters SU, Person RE, Garnica A, Cheung SW, Beaudet AL. 2008. Prader-Willi phenotype caused by paternal deficiency for the HBII-85 C/D box small nucleolar RNA cluster. Nature Genetics 40:719-721. DOI: https://doi.org/10.1038/ng.158, PMID: 18500341

Schmauss C. 2003. Serotonin 2 C receptors: suicide, serotonin, and runaway RNA editing. The Neuroscientist 9 : 237-242. DOI: https://doi.org/10.1177/1073858403253669, PMID: 12934707

Seitz H. 2020. Hebras_et_al_2020. Software Heritage. 1b96b6f. https://archive.softwareheritage.org/swh:1:dir: 1 f87d75f7ffd9805233baa3999255be6a445ddd5; origin=https://github.com/HKeyHKey/Hebras_et_al_2020;visit= swh:1:snp:bc34893ab3e1364f91 cf734d9d044fca7c01d6be;anchor=swh:1:rev: 1b96b6f5e8d479eb43f12f6687f04d4a60f4e305/

Sharma S, Yang J, van Nues R, Watzinger P, Kötter P, Lafontaine DLJ, Granneman S, Entian KD. 2017. Specialized box C/D snoRNPs act as antisense guides to target RNA base acetylation. PLOS Genetics 13: e1006804. DOI: https://doi.org/10.1371/journal.pgen.1006804, PMID: 28542199

Skryabin BV, Gubar LV, Seeger B, Pfeiffer J, Handel S, Robeck T, Karpova E, Rozhdestvensky TS, Brosius J. 2007. Deletion of the MBII-85 snoRNA gene cluster in mice results in postnatal growth retardation. PLOS Genetics $\mathbf{3}$ : e235. DOI: https://doi.org/10.1371/journal.pgen.0030235, PMID: 18166085

Spoida K, Masseck OA, Deneris ES, Herlitze S. 2014. Gq/5-HT2c receptor signals activate a local GABAergic inhibitory feedback circuit to modulate serotonergic firing and anxiety in mice. PNAS 111:6479-6484. DOI: https://doi.org/10.1073/pnas.1321576111, PMID: 24733892

Stamm S, Gruber SB, Rabchevsky AG, Emeson RB. 2017. The activity of the serotonin receptor 2C is regulated by alternative splicing. Human Genetics 136:1079-1091. DOI: https://doi.org/10.1007/s00439-017-1826-3, PMID: 28664341 
Tan Q, Potter KJ, Burnett LC, Orsso CE, Inman M, Ryman DC, Haqq AM. 2020. Prader-Willi-Like Phenotype Caused by an Atypical 15q11.2 Microdeletion. Genes 11:128. DOI: https://doi.org/10.3390/genes11020128

Tecott LH, Sun LM, Akana SF, Strack AM, Lowenstein DH, Dallman MF, Julius D. 1995. Eating disorder and epilepsy in mice lacking 5-HT2c serotonin receptors. Nature 374:542-546. DOI: https://doi.org/10.1038/ 374542a0, PMID: 7700379

Thuilleaux D, Laurier V, Copet P, Tricot J, Demeer G, Mourre F, Tauber M, Jauregi J. 2018A model to characterize psychopathological features in adults with Prader-Willi syndrome. American Journal of Medical Genetics Part A 176:41-47. DOI: https://doi.org/10.1002/ajmg.a.38525

Vitali P, Basyuk E, Le Meur E, Bertrand E, Muscatelli F, Cavaillé J, Huttenhofer A. 2005. ADAR2-mediated editing of RNA substrates in the nucleolus is inhibited by C/D small nucleolar RNAs. Journal of Cell Biology 169:745753. DOI: https://doi.org/10.1083/jcb.200411129, PMID: 15939761

Vitali P, Kiss T. 2019. Cooperative 2'-O-methylation of the wobble cytidine of human elongator tRNAMet(CAT) by a nucleolar and a cajal body-specific box C/D RNP. Genes \& Development 33:741-746. DOI: https://doi. org/10.1101/gad.326363.119, PMID: 31171702

Wahlstedt H, Daniel C, Ensterö M, Ohman M. 2009. Large-scale mRNA sequencing determines global regulation of RNA editing during brain development. Genome Research 19:978-986. DOI: https://doi.org/10.1101/gr. 089409.108, PMID: 19420382

Wang Q, O'Brien PJ, Chen CX, Cho DS, Murray JM, Nishikura K. 2000. Altered G protein-coupling functions of RNA editing isoform and splicing variant serotonin2C receptors. Journal of Neurochemistry 74:1290-1300. DOI: https://doi.org/10.1046/j.1471-4159.2000.741290.x, PMID: 10693963

Watkins NJ, Bohnsack MT. 2012. The box C/D and H/ACA snoRNPs: key players in the modification, processing and the dynamic folding of ribosomal RNA. Wiley Interdisciplinary Reviews: RNA 3:397-414. DOI: https://doi. org/10.1002/wrna.117, PMID: 22065625

Xu Y, Jones JE, Kohno D, Williams KW, Lee CE, Choi MJ, Anderson JG, Heisler LK, Zigman JM, Lowell BB, Elmquist JK. 2008. 5-HT2CRs expressed by pro-opiomelanocortin neurons regulate energy homeostasis. Neuron 60:582589. DOI: https://doi.org/10.1016/j.neuron.2008.09.033, PMID: 19038216

Xu Y, Berglund ED, Sohn JW, Holland WL, Chuang JC, Fukuda M, Rossi J, Williams KW, Jones JE, Zigman JM, Lowell BB, Scherer PE, Elmquist JK. 2010. 5-HT2CRs expressed by pro-opiomelanocortin neurons regulate insulin sensitivity in liver. Nature Neuroscience 13:1457-1459. DOl: https://doi.org/10.1038/nn.2664, PMID: 21037584

Yang T, Adamson TE, Resnick JL, Leff S, Wevrick R, Francke U, Jenkins NA, Copeland NG, Brannan Cl. 1998. A mouse model for Prader-Willi syndrome imprinting-centre mutations. Nature Genetics 19:25-31. DOI: https:// doi.org/10.1038/ng0598-25, PMID: 9590284

Yi-Brunozzi HY, Easterwood LM, Kamilar GM, Beal PA. 1999. Synthetic substrate analogs for the RNA-editing adenosine deaminase ADAR-2. Nucleic Acids Research 27:2912-2917. DOI: https://doi.org/10.1093/nar/27.14 2912, PMID: 10390533

Zanella S, Watrin F, Mebarek S, Marly F, Roussel M, Gire C, Diene G, Tauber M, Muscatelli F, Hilaire G. 2008. Necdin plays a role in the serotonergic modulation of the mouse respiratory network: implication for PraderWilli syndrome. Journal of Neuroscience 28:1745-1755. DOI: https://doi.org/10.1523/JNEUROSCI.4334-07. 2008, PMID: 18272695

Zhang Z, Shen M, Gresch PJ, Ghamari-Langroudi M, Rabchevsky AG, Emeson RB, Stamm S. 2016. Oligonucleotide-induced alternative splicing of serotonin $2 \mathrm{C}$ receptor reduces food intake. EMBO Molecular Medicine 8:878-894. DOI: https://doi.org/10.15252/emmm.201506030, PMID: 27406820

Zhou L, Sutton GM, Rochford JJ, Semple RK, Lam DD, Oksanen LJ, Thornton-Jones ZD, Clifton PG, Yueh CY, Evans ML, McCrimmon RJ, Elmquist JK, Butler AA, Heisler LK. 2007. Serotonin 2C receptor agonists improve type 2 diabetes via melanocortin-4 receptor signaling pathways. Cell Metabolism 6:398-405. DOI: https://doi org/10.1016/j.cmet.2007.10.008, PMID: 17983585

Zhu H, Urban DJ, Blashka J, McPheeters MT, Kroeze WK, Mieczkowski P, Overholser JC, Jurjus GJ, Dieter L, Mahajan GJ, Rajkowska G, Wang Z, Sullivan PF, Stockmeier CA, Roth BL. 2012. Quantitative analysis of focused a-to-I RNA editing sites by ultra-high-throughput sequencing in psychiatric disorders. PLOS ONE 7:e43227. DOI: https://doi.org/10.1371/journal.pone.0043227, PMID: 22912834 